\title{
Contaminants in aquaculture: overview of analytical techniques for their determination
}

Celine I.L. Justino, ${ }^{\mathrm{a}, \mathrm{b},}$, Kátia R. Duarte ${ }^{\mathrm{a}}$, Ana C. Freitas ${ }^{\mathrm{a}, \mathrm{b}}$, Teresa S.L. Panteleitchouk ${ }^{\mathrm{b}}$, Armando C. Duarte ${ }^{\text {a }}$, Teresa A.P. Rocha-Santos ${ }^{\mathrm{a}}$

${ }^{\mathrm{a} D e p a r t m e n t}$ of Chemistry \& CESAM, University of Aveiro, Campus de Santiago, 3810-193 Aveiro, Portugal

${ }^{b}$ ISEIT/Viseu, Instituto Piaget, Estrada do Alto do Gaio, Galifonge, 3515-776 Lordosa, Viseu, Portugal

*Corresponding author: celinejustino@ua.pt (Celine I.L. Justino)

Tel.: +351232910 100; Fax: +351232910183.

\section{Highlights}

- Determination of contaminants in aquaculture samples is crucial for controlling food safety hazards.

- Contaminants can enter in aquaculture mainly in feed and transferred to organisms.

- We discuss analytical techniques for aquaculture contaminants.

- The main contaminants are polychlorinated biphenyls, organochlorinated pesticides, and antibiotics.

\section{Abstract}

Increasing attention has been focused on the presence of contaminants (e.g., polycyclic aromatic hydrocarbons, polychlorinated biphenyls, organochlorinated pesticides, potentially toxic elements, as well as residues of veterinary drugs and antibiotics) in aquaculture products (fish, crustaceans, and molluscs). Such contaminants enter in aquaculture mainly in feed and they are transferred to organisms. Sensitive and reliable determination of contaminants in aquaculture samples become crucial for controlling food safety hazards, and the efficient assessment of extraction and clean-up methods is essential to contribute to overall data quality.

This overview discusses the analytical techniques for determination of contaminants in aquaculture which could interfere with the food safety of produced organisms such as fish, crustaceans, and molluscs. The comparison of the concentrations of contaminants found in the aquaculture products with those established in global or European legislations for foodstuffs 
are also considered. Finally, future perspectives on the determination of aquaculture contaminants are also proposed.

Keywords: aquaculture products, chromatography, clean-up, contaminants, extraction, fish, mass spectrometry, shellfish.

\section{Introduction}

Aquaculture is one of the pillars of the European Union Blue Growth Strategy and its development can contribute to the Europe 2020 Strategy [1]. The aquaculture is defined as the rearing or cultivation of aquatic organisms using techniques designed to increase the production of those organisms beyond the natural capacity of the environment [2]. Aquaculture is also known as fish and shellfish farming under controlled conditions in marine or freshwater environments. Marine aquaculture usually takes place in cages on the seafloor or suspended in the water column, and the species most produced are oysters, clams, mussels, shrimp, and salmon; freshwater aquaculture usually takes place in ponds or in recirculating aquaculture tanks, and the species most produced are catfish, trout, tilapia, and bass [3].

According to the last issue of "The State of World Fisheries and Aquaculture" published by the Food and Agricultural Organization of the United Nations [4], the aquaculture is continuing its impressive growth, in both increased quantity and improved quality. The world aquaculture production attained 90.4 million tons in 2012 including 66.6 million tons of food fish (e.g., finfishes, crustaceans, molluscs, and amphibians) for human consumption [4]. Such world food fish aquaculture production has been continuously increased from approximately 13 million tons in 1990 to 32 million tons in 2000 and to 67 million tons in 2012 [4]. The average annual rate for the aquaculture production has increased from 5.7\% in 2008 to $6.9 \%$ in 2012 [4]. The higher production is located in Asian countries with 88.4\% in 2012 where China accounted alone $61.7 \%$ of total production; Europe accounted $4.3 \%$ of the total global aquaculture production in 2012 [4]. The main species produced in European aquaculture in weight terms (in 2011) are mussels (mainly Mytilus galloprovincialis and M. edulis, 456000 tons, $36 \%$ of total EU production), rainbow trout (mainly Onchorynchus mykiss, 179000 tons, $14 \%$ of total EU production), Atlantic salmon (mainly Salmo salar, 171000 tons, $13 \%$ of total EU production), Pacific cupper oysters (mainly Crassistrea gigas and Ostrea edulis, 104000 tons, $8 \%$ of total EU production), gilthead sea bream (Sparus aurata, 99000 tons, $8 \%$ of total 
EU production), European sea bass (Dicentrarchus labrax, 73000 tons, 6\% of total EU production), and common carp (Cyprinus carpio, 62000 tons, 5\% of total EU production) [5].

The aquaculture production can be developed in extensive or intensive systems, according to the respective low or higher fish density. In extensive systems, organisms grow in lagoons or brackish waters naturally fed while in intensive systems they are bred in tanks and fed with special feeds according to each single species; the semi-intensive systems can also occurs when the natural diet is supplemented with special feeds [6].

The main objective of aquaculture is the production of high nutritional value foods for human consumption. However, apart its valuable food supply and economic support for many countries, the aquaculture practice can cause environmental problems such as pollution of surrounding waters with nutrients, solid wastes, and chemicals (e.g., antibiotics) that are used for disease control in the aquaculture tanks. Regarding chemical contaminants (concentration and duration of exposure), the ingredients of commercial animal feeds can be responsible for food safety risks in aquaculture; the major animal feed contaminants reported are veterinary drug residues, persistent organic pollutants, pesticides, metals and mineral salts (mercury, lead, cadmium, hexavalent chromium, arsenic, and selenium) [7]. The typology of feeds and the quality of waters can be considered important critical factors in fish farming [8]. The exchanges between fish body, water and food can be described by uptake via food and water, and losses via metabolism, growth dilution, egestion, and gills [9]. The contaminants present in aquaculture, whether intentionally or unintentionally, can be metabolized and excreted (such as veterinary drugs), detected at residual levels, or accumulated in fish. The bioaccumulation of toxic contaminants by farmed fish, bivalves, crustaceans, and molluscs becomes a serious environmental problem and mainly related to human supply. As stated by the European Food Safety Authority [10] and Håstein et al. [11], the contaminant concentration in farmed fish and shellfish depends to various factors such as the species, the capture season, the origin, the development state, and the tissue, and the levels vary within species and between species in both wild and farmed fish [10]. Comparative studies have demonstrated that man-made contaminants such as pesticides, polybrominated biphenyl ethers (PBDE), and polychlorinated biphenyls (PCB) were found at higher concentrations in farmed fish than in wild fish (salmon, catfish, turbot, and sea bass) [12], but there is a need for standardization of sampling procedures before a robust comparison of wild and farmed fish can be made [10].

The sample preparation is an important step in the analysis of contaminants from environmental samples due to the matrix effects occurred which are directly associated to the 
complexity of such environmental matrices [13]. Regarding the determination of contaminants in aquaculture matrices, it is widespread that such matrices are complex and the presence of a large content of fat and other interfering substances are co-extracted with the analytes of interest. Thus, the choice of the extraction method or combination of extraction methods together with the clean-up procedures should be well defined to obtain extracts with minimal fat content for further efficient analysis of contaminants. The determination of contaminants in aquaculture is crucial to the control of food safety of produced organisms. The organic enrichment of aquaculture waters from sediments is also an important topic, and the analysis of contaminants in water and sediments is also required to the monitoring of water quality.

This paper has the objective of reviewing the state of the art of current analytical techniques published in the recent period of 2008-2015 and used for the determination of contaminants, that is, polycyclic aromatic hydrocarbons (PAH), brominated flame retardants (BFR), PCB, organochlorinated pesticides (OCP), potentially toxic elements, residues of veterinary drugs and antibiotics, in various samples from aquaculture such as fish, crustaceans, and molluscs. The occurrence of such contaminants in aquaculture and the analytical procedures required before analysis, such as extraction and clean-up are also discussed.

\section{Occurrence of contaminants in aquaculture}

Aquaculture has been increasingly used to produce foodstuffs such as fish and shellfish and it has been strictly controlled by global and European regulations in order to define maximum levels of substances in such products. For example, the EC 1881/2006 regulated the maximum levels of contaminants such as metals $(\mathrm{Pb}, \mathrm{Hg}$, and $\mathrm{Cd})$ and $\mathrm{PAH}$ in foodstuffs such as muscle of fish, crustaceans, and bivalve molluscs [14], the EC 1259/2011 regulated the maximum levels for dioxins, dioxin-like PCB and PCB in foodstuffs such as muscle of fish and fishery products [15], the EC 37/2010 regulated the maximum residues limits of antibiotics (e.g., ciprofloxacin, enrofloxacin, danofloxacin, oxolinic acid, flumequine, sulphonamides, tetracyclines, and penicillins) in foodstuffs of animal origin (e.g., muscle, fat, liver, and kidney of food producing species) [16], and directive 86/363/EEC regulated the maximum levels for pesticide residues (e.g., DDT, HCB, and $\mathrm{HCH}$ ) in foodstuffs of animal origin [17]. Among the chemical contaminants present in farming aquatic environment, the persistent organic compounds including the organochlorine contaminants have a strong 
tendency to reach very high levels in fatty tissues at the end of the food chain [11] due to bioaccumulation in fish fatty tissues and biomagnification along the food chain. The organochlorine compounds are frequently detected in human lipid tissues and fluids such as human breast milk, and the consumption of fish is a possible source as reported by Muñoz de Toro et al. [18], Tsukino et al. [19], and Someya et al. [20], where organochlorine compounds (mainly DDT and PCB) were registered in Argentine, Japanese, and Indian women, respectively. Thus, the contaminants such as metals and organochlorine compounds are measured in the muscle tissues of fish to define food quality for human consumption, but also in the fish liver because it is considered the preferred accumulating organ for metals [21].

Various metals are present in the aquatic environment via geochemical processes and anthropogenic industrial sources, where they can be accumulated along the food chain. Thus, fish could accumulate metals from aquatic environment and from uptake through feeds [22]. Cretì et al. [6] reported that: a) metal ions dissolved in waters are absorbed through the gills and other permeable body surfaces; or b) metals bound to solid particles are ingested, detached from their carrier particles in the digestive system, and absorbed through the gut epithelium. For example, Fernandes et al. [21] verified that the level of metals in muscle is significantly lower than in liver $(p<0.05)$, particularly $\mathrm{Cu}\left(1-4 \mu \mathrm{g} \mathrm{g}^{-1}\right.$ in muscle $v s$. $100-900$ $\mu \mathrm{g} \mathrm{g}^{-1}$ in liver) and Cd (up to $0.03 \mu \mathrm{g} \mathrm{g}^{-1}$ in muscle $v s .0 .4-1.2 \mu \mathrm{g} \mathrm{g}^{-1}$ in liver). Elements such as $\mathrm{Fe}, \mathrm{Zn}, \mathrm{Cu}, \mathrm{Co}, \mathrm{Mn}, \mathrm{Cr}, \mathrm{Se}$, and $\mathrm{Ni}$ are essential for the normal metabolism in fish [23], but a high accumulation can cause an increase in mortality and higher occurrence of deformities in rainbow trout $(O$. mykiss $)$ and growth reduction of European sea bass (D. labrax) as well as mortality, deformation and low hatching success for carp (Cyprinus carpio) larvae [24]. A special attention should be given to the presence of mercury in aquatic environment, mainly in fish and shellfish, which can concentrate the metal in their bodies, mostly in the organic form of methyl mercury. The toxicity of organic mercury is higher than its inorganic form due to the high solubility of methyl mercury in lipids and its low elimination rate from the organism, causing bioaccumulation [25]. The consumption of contaminated fish, and other seafood that bioaccumulate organic mercury, is the main pathway for human exposure, even when present at trace levels. Methyl mercury can cause severe neurological damage to humans, in the form of physical lesions manifested as tingling and numbness of fingers and toes, loss of coordination, difficulty in walking, or tremors [25]. To the best of our knowledge, there are no studies reporting the contamination of aquaculture products with mercury and methyl mercury. 
PAH are environmental lipophilic contaminants that have natural and anthropogenic origins such as the partial combustion of organic compounds and pollution from petrochemical activities, and $16 \mathrm{PAH}$ are present in the EPA priority pollutants list, which has actually a total of 126 substances [26]. In marine environment, the main entry of PAH is through atmospheric depositions and surface runoff, and they could contaminated aquaculture sediments, then entering in the food chain through seafood to humans [27;28]. Furthermore, European Commission Regulation 1881/2006 has fixed maximum levels for certain contaminants such as PAH in foodstuffs such as fish, in order to keep them as toxicologically acceptable for public health [14].

Persistent organohalogenated compounds such as BFR, OCP and PCB have been considered as environmental contaminants, and although some of them have been restricted and banned, they are used in agriculture, industry, and household applications [29]. For example, the PBDE are one of the most studied BFR due to their persistence and lipophilic nature concentrating in fatty tissues of aquaculture organisms such as fish and shellfish, which allow their accumulation along the food chain [30]. Blanco et al. [30] have verified that PBDE in the feeds (2.35-4.76 $\left.\mathrm{ng} \mathrm{g}^{-1}\right)$ were reflected in turbot fillets $\left(0.54-2.05 \mathrm{ng} \mathrm{g}^{-1}\right)$, and particularly for tetra-BDE 49 , that only $2 \%$ were accounted in the feed further contributing to $15 \%$ of total PBDE in turbot fillets, as a consequence of bioaccumulation. Concerning DDT and its degradation product (DDE), they are hydrophobic and accumulate preferentially in adipose tissues [31]. According to Yu et al. [32], the abundances of p,p'-DDT and BDE-209 and their metabolites ( $p, p^{\prime}-\mathrm{DDE}$ and BDE-47, respectively) in fish indicated the occurrence of DDT and PBDE biotransformation in fish body. The PCB are organic compounds with one to 10 chlorine atoms attached to a biphenyl ring system, and the 209 PCB congeners (also defined as PCDD: polychlorinated dibenzo-p-dioxins, and PCDF: polychlorinated dibenzofurans) are grouped into: a) non dioxin-like PCB, where one or more chlorine atoms in an ortho-position and benzene rings on a different plane that do not share the dioxin's toxic mechanism; and, b) dioxin-like PCB, where chlorine atoms are in a meta- or para-position [8;33]. The non dioxin-like PCB act on the endocrine system after bioaccumulation in the body upon long-term intake and some of them have also been shown to elicit neurological, immunological and carcinogenic effects [33]. Six PCB congeners (PCB congeners 28, 52, 101, 138, 153 and 180, being the 138 and 153 the two most detected) were considered as indicators for the occurrence of non dioxin-like PCB in feed and food because it was estimated that their sum represents about $50 \%$ of the total non dioxin-like PCB in food [33]. Regarding dioxin-like PCB, they show toxicological properties similar to dioxins, including 
12 compounds [33]. Usually, PCB enter in the environment as a result of improper disposal practices or leaks in transformers and hydraulic systems [34]. The fish can bioaccumulate, biomagnify and bioconcentrate contaminants ingested with food or taken up directly from the water via diffusion across the gills and skin. An interesting study was recently developed by Perugini et al. [34] where the level and distribution of 18 PCB congeners were correlated in farmed rainbow trout and in feed used during the last phase of their breeding. Perugini et al. [34] verified that positive correlation was obtained for PCB congeners 95, 101, 118, 138, 149, $151,153,183$ (between $r=0.370$ and $r=0.587$ ) and the sum of the 18 PCB analyzed in feed was positively correlated ( $p<0.01$ and $r=0.451)$ with the sum of PCB in rainbow trout muscles. Taking into account such considerations, Perugini et al. [34] referred that feed is the primary contaminant source to rainbow trout and plays a large role in the accumulation by fish. Perugini et al. [34] also referred that no correlation was obtained with the other 10 PCB congeners (PCB congeners 28, 52, 99, 105, 110, 146, 170, 180, and 187), which could be due to the metabolic processes, during the trout life, that modify PCB concentrations and their distribution in fish tissues. Faced to such findings, more aquaculture studies should be developed to support the correlation between feed as contaminant source and fish tissue contamination.

Regarding antimicrobial drugs such as macrolide, malachite green, ivermectin, imidazoles, nitrofurans, as well as antibiotics such as oxytetracycline, chloramphenicol, and oxolinic acid (a quinolone), they have been found in some aquaculture products. Antimicrobials such as antibiotics (mainly tetracyclines and sulfonamides) and antifungals are commonly used in aquaculture to prevent or treat fish bacterial diseases, which are associated to stress conditions such as high fish density, hypoxia, high nitrite, and ammonia concentrations [35]. Some of them such as chloramphenicol, malachite green, and nitrofurans (e.g., furazolidone, furaltadone, nitrofurazone, and nitrofurantoin) have been banned in aquaculture practice for food safety reasons, and the permitted antibiotics grouped in EU list include tetracyclines, penicillins, quinolones, sulphonamides, and trimethoprim [16]. Each country has established regulations about the use of antimicrobials in aquaculture but it was shown that the banned antimicrobials are still used in aquaculture farms as reported in the recent work of Conti et al. [35], where nitrofurans were found in aquacultured fish (Italy). Thuy et al. [36] referred that once antibiotics are released into the waters or sediments, they are subjected to transformation or degradation at various rates, depending on the nature of the antibiotic and environmental factors such as light, temperature, and/or microbial activities. 
According to Håstein et al. [11], the malachite green, which is an industrial dye that has effectively been used to treat fungal infections in fish, is not permitted in aquaculture, but the active substance and its metabolite, leuco-malachite green, are still detected in fish and fish products. Among veterinary drugs, the antibiotics (e.g., enrofloxacin) and their metabolites (e.g., ciprofloxacin) have also been applied in aquaculture production (through medicated feed or by addition directly in water) for the prevention and treatment of bacterial infestations, which can be responsible for serious economic losses [37]. The European Commission Decision 37/2010 regulated the prudent use of pharmacologically active substances providing the maximum residues limits (MRL) of allowed substances as the tolerance levels in foodstuffs of animal origin [16]. For example, for total sulfonamide, a tetracycline residue, a level of $100 \mu \mathrm{g} \mathrm{kg}^{-1}$ was allowed in fish by the European Union in order to guarantee the safety of such aquaculture product [16]. The European Commission Decision 37/2010 also identifies 9 chemical pharmacologically active substances (chloramphenicol, chloroform, chlorpromazine, colchicines, dapsone, dimetridazole, metronidazole, nitrofurans including furazolidone, and ronidazole) which are prohibited and for which MRL cannot be established because residues of those substances, at whatever limit, constitute a hazard to human health [16].

To the best of our knowledge, little information is found about the presence of contaminants in aquaculture wastewaters, which constitutes an important topic in the characterization and distribution of such substances in the aquaculture. According to Thuy et al. [36], where the occurrence and potentially environmental risks of antibiotics released from shrimp farming are reviewed, several antibiotics commonly used in Vietnamese shrimp culture (mainly norfloxacin, oxolinic acid, trimethoprim, and sulfamethoxazole) have been detected in wastewater and sediments of the aquaculture ponds, as well as in surrounding coastal wetlands. Zheng et al. [38] also reported that the concentrations of erythromycin- $\mathrm{H}_{2} \mathrm{O}$, sulfamethoxazole, and sulfadimidine in the vicinity of aquaculture activities were higher, suggesting that a higher intensity of aquaculture activities could contribute to increasing levels of antibiotics in the environment. Thus, further studies should be developed in this field mainly due to the multi-factor dependence such as nature of the antibiotic and environmental factors (e.g., light, temperature and/or microbial activities) on the transformation/degradation of antibiotics in aquatic environment [36]. On the other hand, and according to Klinger an Naylor [39], the wastewater from aquaculture is composed of uneaten feeds, feces, and bacteria (particulate organic matter), as well as excreted ammonia, nitrite, nitrate, and phosphorus compounds (dissolved inorganic nutrients), and the two major problems are: a) if 
waste products remain in the aquaculture system, they can accumulate to levels that are toxic to fish and other organisms; and, b) if they are released into the environment, they can change (eutrophicate) aquatic ecosystems, which are often nitrogen and phosphorus limited. Recently, Liu et al. [40] referred that most marine aquaculture farms (from China) are on a small scale and do not have wastewater treatment facilities.

\section{Sampling, extraction and clean-up methods}

Table 1 displays results of recent works on the determination of contaminants in aquaculture samples, where extraction and clean-up methods are also identified.

\section{$<$ Table $1>$}

For the majority of the works reported in Table 1, the following procedure have been considered: a) fishes are collected from aquaculture sites and transported alive to the laboratory in zip-lock polyethylene bags or wrapped in aluminium foil; b) fishes are eviscerated and peeled and their edible tissues such as muscle, liver, and bile are separated, mixed and homogenized using a blender; then, the different samples were kept in a freezer $( \pm$ $-20^{\circ} \mathrm{C}$ ) until extraction; c) the surface sediments samples were collected from aquaculture ponds (e.g., using Peterson grab or Day Grab samplers) and in the laboratory, they were sieved to remove large debris and stored in glass containers at $-20^{\circ} \mathrm{C}$ until extraction. In some cases, the sieved sediments and the overlying waters were mixed to prepare sediment slurries (with $10 \%$ solids). In other works, the sediment samples were freeze dried, ground, and homogenised. The dried sediment samples are then directly used for extraction; and, d) water samples were collected in glass bottles, transported to the laboratory in refrigerated boxes $\left(4^{\circ} \mathrm{C}\right)$, then acidified (generally with $0.3 \% \mathrm{HNO}_{3}$ ) and stored at $4^{\circ} \mathrm{C}$ until analysis.

After the sampling of aquaculture animals, their edible tissues are separated and used for extraction of organic compounds or potentially toxic elements. Table 1 shows that the extraction of organic compounds follows two tendencies according to the aquaculture samples: a) for fish and shellfish, the extraction of contaminants is based mainly in simple solvent extraction where one or two extraction solvents were used. Liquid-solid extraction using Soxhlet apparatus have been reported in various works, as shown in Table 1, for the extraction of $\mathrm{PCB}$ and $\mathrm{OCP}$, and green extraction methods [e.g., pressurized liquid extraction 
(PLE) and supercritical fluid extraction (SFE)] were also used but at fewer times; and b) for sediments, the Soxhlet extraction (mainly with dichloromethane) is preferred to simple solvent extraction with only one work using PLE.

Regarding the extraction of metals both from fish or sediments, the digestion with nitric acid is the most used (Table 1). For example, in the work of Cretì et al. [6], concentrated $\mathrm{HNO}_{3}(65 \%)$ was used as $1 \mathrm{~mL}$ for each $50 \mathrm{mg}$ of wet fish tissue. Then, the mixture was heated at $70^{\circ} \mathrm{C}$, cooled and centrifuged for 15 minutes before determination of metals. Jiang et al. [54] also used $\mathrm{HNO}_{3}$ for digestion in a Teflon digestion vessel ( $2 \mathrm{~mL}$ for each $200 \mathrm{mg}$ of fish tissues) at $60^{\circ} \mathrm{C}$. An additional step was reported by cooling the sample at room temperature and adding $\mathrm{H}_{2} \mathrm{O}_{2}(30 \%)$ for another digestion with a microwave digestion unit at different conditions before the analysis of metals [54].

The simple solvent extraction through the ethyl acetate was generally used for the extraction of steroids by Liu et al. [40] or nitrofurans metabolites by $\mathrm{Yu}$ et al. [59] from aquaculture sediments (Table 1). Dimethylformamide was used to extract nitrofurans from aquaculture sediments by $\mathrm{Yu}$ et al. [59] and it was the best extracting solvent (recoveries of 79.0-82.7\%) when compared with methanol (82.5-105.8\%), acetonitrile (93.5-106.6\%), and a mixture of methanol and acetonitrile (97.8-109.2\%) due to the recovery consistency in various sediments samples. Gadaj et al. [48] also used the organic solvent extraction but with acetonitrile to extract nitroimidazole drugs from fish tissues (Table 1). In the extraction step, Gadaj et al. [48] also used $\mathrm{NaCl}$ since it removes highly water-soluble polar matrix interferences in further MS analysis.

The liquid-solid extraction using Soxhlet apparatus is also a most common method widely used to extract: a) PAH from sediments, as shown in the works of Wang et al. [57], Specchiulli et al. [58], and Retnam et al. [28]; and b) persistent organohalogenated compounds such as OCP, PCB and BFR from fish tissues and shellfish, as shown in Table 1. The Soxhlet extraction is usually used to extract organic compounds from lipid containing matrices but as it uses large amounts of toxic solvents and it is also time-consuming, clean-up procedures are required in order to remove fat and lipids for further separation in gas chromatography (GC) [29].

In latest years, the green extraction methodologies have been increasingly used. They are clean and environmentally friendly techniques where the reduction of both the amount and the toxicity of solvents and reagents constitute the major advantage [61]. As shown in Table 1, the PLE was the most used green technique for the extraction of organic compounds, mainly $\mathrm{PCB}$, for fish muscle [8;34]. One of the main advantages of this extraction technique is the 
short time periods (5-10 min) requested for the extraction of compounds in solid and semisolid samples which together with the high temperatures increased the extraction efficiency due to the employment of solvation power [61]. In addition, PLE provides high extraction efficiency with low solvent volumes $(15-40 \mathrm{~mL})$, also employing large amount of sample (up to $100 \mathrm{~g}$ ); it is also easy to use, automated, and filtration is not required [62;63]. The SFE is also a commonly used green extraction methodology and it is fast and selective. The SFE is based on extracting analytes in a solid sample by a fluid in supercritical conditions, which is any liquid at a temperature and pressure above its critical point, where distinct liquid and gas phases do not exist; the $\mathrm{CO}_{2}$ is widely used as supercritical solvent since it shows several environmental advantages such as safety, non-toxicity, and costeffectiveness [61;62]. Rodil et al. [29] reported the determination of 15 persistent organohalogenated pollutants that is $\mathrm{OCP}, \mathrm{PCB}$, polybrominated biphenyls (PBB) and BFR such as PBDE from marine aquaculture samples (clam, mussel and cockle) (Table 1). Rodil et al. [29] have used the SFE methodology with supercritical $\mathrm{CO}_{2}$ previously optimizing its parameters (extraction temperature, pressure, static extraction time, dynamic extraction time, and carbon dioxide flow rate) through a Doehlert design after identifying the significant factors (pressure at 165 bar and dynamic extraction time of $27 \mathrm{~min}$ ) by a screening study (fractional factorial design). The extraction was made simultaneously with the clean-up procedure where the fat interferences were eliminated through a combination of acidic silica gel and aluminium oxide basic in the extraction chamber, obtaining a fat remaining in the extracts below $0.1 \%$.

The combination of various techniques for the extraction of target analytes can lead to higher efficiency eliminating interfering compounds in the determination technique. NácherMestre et al. [27] have combined alkaline saponification and SPE for that purpose (Table 1), eliminating interfering compounds, mainly fat from the extracts obtaining from fish fillet with fat content up to $100 \%$. The multi-residue and multi-class determination of analytes is very sought in environmental analysis due to the higher analysis throughput, and it is encouraged by the FDA to be used in regulatory analysis. The limitation is the need of a complex sample treatment, which is the most critical step in order to obtain good recovery values for as many compounds as possible. The double-step extraction is a strategy used to overcome the complex sample treatment, which should be versatile to ensure the extraction of all compounds, as shown in the work of Gbylik et al. [52], where $m$-phosphoric acid and heptafluorobutyric acid as an ion-pair agent and acetonitrile were used for the extraction of aminoglycosides, $\beta$-lactams, fluoroquinolones, macrolides, sulfonamides, trimethoprim, and 
tetracyclines). The choice of the extraction mixture is critical when a multi-class method is further used due to the different affinities between the extraction solvent and the different compounds. For example, for the analysis of $\beta$-lactams, macrolides, sulphonamides, and fluoroquinolones, the use of organic solvents such as acetonitrile or methanol as extraction solvent gave the best results whereas for aminoglycosides, which are strongly polar and stable in the presence of acids, only high ionic-strength extraction solvents are recommended [52], and a two-step extraction of the same sample can be considered as a strategy for the simultaneous determination of such antibiotics [52]. Freitas et al. [45] proposed a method for the simultaneous determination of 41 antibiotics from seven different classes (sulphonamides, trimethoprim, tetracyclines, macrolides, quinolones, penicillins, and chloramphenicol) in gilthead sea bream testing fourteen procedures for sample treatment. The different procedures include simple solvent extraction with acetonitrile, EDTA, methanol, or combinations between them, and some including a SPE step also testing two SPE sorbents [reverse-phase C18 and hydrophilic and lipophilic balance modified polymer (HLB)]. The best option for all compounds was the simple solvent extraction with EDTA and acetonitrile, without the SPE step, due to the overall better recoveries [45]. Freitas et al. [45] also stated that the acetonitrile was shown to be more efficient for a higher number of compounds when compared with methanol or even a combination of both solvents.

Although the SPE is usually used as extraction methodology, it can also be used in the clean-up process, as shown in Table 1. Usually, the complex samples were cleaned up by SPE and sorbents are chosen according to the affinity, capacity, and selectivity required. The most popular clean-up strategy includes the SPE with reverse phase C18, silica or strong cationexchange cartridges in order to remove the interferences in the sample. In the work of Li and Kijak [51], after the solvent extraction with $\mathrm{MeOH}: \mathrm{ACN}$, an online SPE system (based on a PolymerX RP-1 guard cartridge) was used for automated sample clean-up in order to remove inorganic salts, protein, fat and/or other endogenous substances from the extract. The online SPE for cleanup procedures is widely used in regulatory laboratories allowing the automation of the process to save labour and to increase reproducibility, as well as robust over many analysis rounds [51]. Other clean-up procedures were used, such as adsorption columns and gel-permeation chromatography. The adsorption columns usually applied were based in sorbents as Florisil, alumina, or silica gel, which were used for the removal of nonpolar lipids present in fatty samples such as fish. According to Huerta et al. [64], the alumina and silica gel columns have similar characteristics, except that alumina columns can be activated to 
work specifically under acid, basic, or neutral conditions; Florisil columns are extremely active and weakly basic for the adsorption of species of low to moderate polarity.

\section{Separation, detection, and determination of contaminants in aquaculture}

Various analytical techniques were suggested to the determination of contaminants in aquaculture samples (Table 1). The LC or GC with MS detection are the techniques proposed as suitable confirmatory methods for organic residues or contaminants in foodstuffs [65]. Effectively, approximately 54\% of the works analysed in this review used the GC or LC combined with MS to the determination of organic compounds in fish or shellfish, as shown in Table 1. The GC-ECD is the second choice in approximately $17 \%$ of works. For the analysis of organic compounds in sediments, the major use of GC-MS and LC-MS was also verified (Table 1). Concerning the chemical elements, the 2002/657/EC suggested that the suitable confirmatory methods are the differential pulse anodic stripping voltammetry (electric signal), atomic absorption spectrometry (absorption wavelength), atomic emission spectrometry (emission wavelength), and mass spectrometry (mass-to-charge ratio) [65]. As shown in Table 1, the atomic absorption spectrometry was in fact used in $43 \%$ of works reporting the analysis of metals in fish, shellfish, and sediments samples, but the majority of works used the ICP-MS as preferable technique (57\%).

According to the literature reported in this review paper, GC is preferred to LC most likely due to the greater selectivity, and resolution for the determination of contaminants in complex matrices such as aquaculture samples [27]. Nácher-Mestre et al. [27] have used GC coupled to tandem MS with a triple quadrupole (GC-(QqQ)MS/MS) for the determination of PAH in complex matrices from aquaculture such as fish fillet (Table 1), and the selected $16 \mathrm{PAH}$ are present in the EPA priority pollutants list [26]. Nácher-Mestre et al. [27] have found concentrations of PAH in fish fillet between 0.06 to $11.4 \mu \mathrm{g} \mathrm{kg}^{-1}$ and higher concentrations to phenanthrene, fluoranthene and pyrene (range of 0.2-11.4 $\mu \mathrm{g} \mathrm{kg}^{-1}$ ); the benzo[a]pyrene was found only in one fish sample but with a high concentration $\left(3.9 \mu \mathrm{g} \mathrm{kg}^{-1}\right)$ which is above the maximum limit $\left(2.0 \mu \mathrm{g} \mathrm{kg}^{-1}\right)$ established by the European Commission 1881/2006 [14].

In the work of Rodil et al. [29], the GC-MS/MS was used to achieve a complete separation for identification and quantification of persistent organohalogenated compounds (OCP, PCB, PBB, and PDBE) from shellfish samples (cockle, clam, and mussel). Rodil et al. [29] have reported appreciable concentrations of PCB in all samples analysed between 0.2 and $45.9 \mathrm{ng}$ $\mathrm{g}^{-1}$ with a mean of $14.3 \mathrm{ng} \mathrm{g}^{-1}$; the higher concentrations were found in mussel for PCB 52 
(40.5 $\mathrm{ng} \mathrm{g}^{-1}$ ) and PCB 153 (45.9 $\mathrm{ng} \mathrm{g}^{-1}$ ). Such concentrations still below the maximum limit for human consumption established by the Commission Regulation 1259/2011 in the muscle of fishery products, which is of $75 \mathrm{ng} \mathrm{g}^{-1}$ for the sum of PCB 28, 52, 101, 138, 153, and 180 [15]. For OCP such as 4,4'-DDT in clam, the concentrations found (117.8 $\left.\mathrm{ng} \mathrm{g}^{-1}\right)$ were lower than those reported in Regulation in use $\left(1 \mathrm{mg} \mathrm{kg}^{-1}\right)$ [17]. Regarding PBDE, only the PBDE47 was found in clam (2.4 $\left.\mathrm{ng} \mathrm{g}^{-1}\right)$. LOD between 0.01 and $0.2 \mathrm{ng} \mathrm{g}^{-1}$ and LOQ between 0.05 and $0.8 \mathrm{ng} \mathrm{g}^{-1}$ were defined as the concentration that gives a response equivalent to three or ten times the standard deviations of the blank, respectively.

The analysis of PCB in aquaculture samples was also reported by Pinto et al. [41], Ferreira et al. [31], Fernandes et al. [21], Russell et al. [55], and Perugini et al. [34] where GC-ECD was used to quantify such organohalogenated compounds (Table 1). Pinto et al. [41] verified that PCB 138 and 153 showed the highest concentration in analysed samples of gilthead sea bream (4.20 and $3.30 \mathrm{ng} \mathrm{g}^{-1}$, respectively), sea bass (4.63 and $4.22 \mathrm{ng} \mathrm{g}^{-1}$, respectively) and mussel (3.03 and $1.99 \mathrm{ng} \mathrm{g}^{-1}$, respectively) in comparison to the other PCB congeners (PCB $28,52,101,118$, and 180), obtaining the mean recovery by PCB standard spiked samples as $70 \pm 7 \%$ for fish and mussels. The same tendency was reported by Perugini et al. [34] where PCB were analysed in rainbow trout muscle (Table 1) showing the greatest concentration of PCB 138 as $15.9 \pm 1.84 \mathrm{ng} \mathrm{g}^{-1}$ and $18.42 \pm 2.27 \mathrm{ng} \mathrm{g}^{-1}$ for PCB 153 , with recoveries between 95 and $125 \%$. Pinto et al. [41] referred the presence of more unsubstituted ring positions on the biphenyl rings is the cause of such high bioconcentration of PCB in analysed aquaculture samples, because they are more slowly metabolized. The lowest concentrations of PCB in fish and mussel tissues were found to PCB 28 and 52 (up to $1.61 \mathrm{ng} \mathrm{g}^{-1}$ ). In the works of Pinto et al. [41] and Perugini et al. [34], the GC-MS was also used as confirmatory method. LOD reported by Pinto et al. [41] were between 0.2 and $0.66 \mathrm{ng} \mathrm{g}^{-1}$ for PCB 180 and PCB 52, respectively. In the work of Perugini et al. [34], where the LOD were estimated by multiplying the appropriate one-sided $99 \% t$-statistic by the standard deviation, LOD ranged from 0.1 and $1.4 \mathrm{ng} \mathrm{g}^{-1}$ for PCB 105 and PCB 153, respectively, and the LOQ was set to 2.5 $\mathrm{ng} \mathrm{g}^{-1}$ for all PCB congeners. Cirillo et al. [8] have only used GC-MS to quantify PCB in fish muscles (Table 1), and the amount of non dioxin-like PCB mean levels (2.7 $\left.\mathrm{ng} \mathrm{g}^{-1}\right)$ are lower that the European Union limit fixed at $75 \mathrm{ng} \mathrm{g}^{-1}$ but the dioxin-like PCB mean levels are higher (86.6 $\mathrm{ng} \mathrm{g}^{-1}$ ) than that reported in legislation [15]. Thus, the lack of contamination found in the analyzed waters for all the chemicals considered, including metals $\mathrm{Pb}$ and $\mathrm{Cd}$, suggests that the contamination found in trout may mainly be attributable to feed according to the literature data [8]. 
Other analytical configurations have been reported in the literature, for example, using ultra high performance LC (UHPLC), which uses smaller diameter particles (around $1.7 \mu \mathrm{m}$ ) in the stationary phase and short columns, allowing higher pressures and narrower LC peaks (5-10 s) and consequently shorter time analysis [66]. The use of smaller amounts of solvents in UHPLC is also an advantage when compared to HPLC-based methods. In addition, the use of tandem MS with the UHPLC provides a decrease in solvent volumes, higher throughput, and improved resolution [44]. Such analytical technique is widely used for the determination of antibiotics as shown in the works of Dasenaki and Thomaidis [50] and Freitas et al. [45], where multi-residue and multi-class determination of antibiotics are provided. For example, Freitas et al. [45] described a method for the simultaneous determination of 41 antibiotics from seven different classes (sulphonamides, trimethoprim, tetracyclines, macrolides, quinolones, penicillins, and chloramphenicol) in gilthead sea bream by UHPLC coupled to tandem MS (UHPLC-MS/MS), where minimal analysis time combining separation, sensitivity, and high resolution chromatography were the main advantages. Gbylik et al. [52] developed a method for the simultaneous determination of 34 antibiotics (aminoglycosides, cephalosporins, fluoroquinolones, macrolides, penicillins, sulfonamides, trimethoprim, and tetracyclines) in fish samples in a single analytical method (LC-MS/MS), Li and Kijak [51] presented a new multi-class, multi-residue HPLC-MS/MS method for measuring 21 veterinary drugs (including 6 sulfonamides, 3 tetracyclines, 8 quinolones, and 4 cationic dyes) in shrimp, and Dasenaki and Thomaidis [50] proposed the UHPLC-MS/MS for determination of 17 sulfonamides and 5 tetracyclines in fish tissues in a single run (Table 1). Figure 1 shows the obtained chromatograms of all 21 drugs determined from shrimp tissues through HPLC system with online SPE capability by Li and Kijak [51]; all peaks have good peak shape and relatively narrow width.

\section{$<$ Figure $1>$}

Jester et al. [47] also used LC-MS/MS for the analysis of nitrofurans drugs in fish but as a confirmatory technique. Jester et al. [47] proposed the determination of nitrofurans by an enzyme-linked immunosorbent assay (ELISA) using less fish tissue and less solvent instead of LC-MS/MS, which is highly expensive. ELISA is a sensitive, rapid, and portable analytical method. When the results were compared, ELISA data were highly correlated with those of LC-MS/MS ( $\mathrm{R}^{2}$ of 0.9769 and 0.9997 for 3-amino-2-oxazolidinone and 3-amino-5- 
morpholino-methyl-2-oxazolidone, respectively), and these kits were further used as screening assays for nitrofuran residues in fish muscle [47]. On the other hand, it can be applied in-situ as screening alert method for a large number of fish samples before their commercialization.

Concerning the quantification of metals in aquaculture samples, the atomic absorption spectrometry (AAS) was commonly used, as shown in Table 1. For example, Fernandes et al. [21] have determined metals $(\mathrm{Cu}, \mathrm{Zn}$, and $\mathrm{Cd})$ in liver and muscles of sea bass with AAS, observing that metal concentrations in the muscle of cultured sea bass were all below the recommended maximum limits for commercial fish species (Cd: $0.5 \mathrm{mg} \mathrm{kg}^{-1}, \mathrm{Cu}: 30 \mathrm{mg} \mathrm{kg}^{-1}$, and $\mathrm{Zn}: 30 \mathrm{mg} \mathrm{kg}^{-1}$ ) [67]. Cretì et al. [6] have studied the bioaccumulation of $\mathrm{Cd}$ and $\mathrm{Pb}$ in various tissues (gill, liver, kidney, gut, and muscle) of sea bream farmed in three different farming systems (intensive, semi-intensive, and extensive systems), and results are showed in Figure 2.

\section{$\langle$ Figure $2>$}

Cretì et al. [6] verified that the different fish tissues show different capacity of accumulation of metals, and levels of both metals $(\mathrm{Cd}$ and $\mathrm{Pb})$ in the various tissues significantly vary ( $p<0.0001)$ among fish culture systems. Cirillo et al. [8] have used the same technique (AAS) and verified that the levels of $\mathrm{Pb}\left(0.225 \mu \mathrm{g} \mathrm{g}^{-1}\right)$ and $\mathrm{Cd}\left(0.007 \mu \mathrm{g} \mathrm{g}^{-1}\right)$ in muscles of rainbow trout did not exceed the limit fixed at 0.30 and $0.05 \mu \mathrm{g} \mathrm{g}^{-1}$, respectively, established by the European Union legislation for fish destined for human consumption [14], which also occurred with the metal levels found in muscles of rainbow trout (below $0.01 \mu \mathrm{g} \mathrm{g}^{-1}$ for $\mathrm{Cd}$ and $0.1 \mu \mathrm{g} \mathrm{g}^{-1}$ for $\mathrm{Pb}$ ) in the work of Cretì et al. [6]. According to Cretì et al. [6], the great amount of $\mathrm{Pb}$ in kidney, liver and gills of fish cultured in the extensive farm practice may be the result of a water contamination caused by environmental pollution. LOD of $0.02 \mu \mathrm{g} \mathrm{g}^{-1}$ for $\mathrm{Pb}$ and $0.0003 \mu \mathrm{g} \mathrm{g}^{-1}$ for $\mathrm{Cd}$ were obtained in the work of Cirillo et al. [8] with LOQ of 0.06 $\mu \mathrm{g} \mathrm{g}^{-1}$ for $\mathrm{Pb}$ and $0.0009 \mu \mathrm{g} \mathrm{g}^{-1}$ for $\mathrm{Cd}$. Better LOD were estimated in the work of Cretì et al. [6] were values of 5-15 $\mathrm{ng} \mathrm{g}^{-1}$ and 1-5 $\mathrm{ng} \mathrm{g}^{-1}$ were found for $\mathrm{Pb}$ and $\mathrm{Cd}$, respectively, which were determined from the standard additions curve for each metal, based on the usual definition of the concentration of the analyte yielding a signal equivalent to three times the standard deviation of the reagent blank signal. The inductively coupled plasma MS (ICP-MS) was also used for the detection of metals by Wu and Yang [53] and Jiang et al. [54]. Wu and 
Yang [53] have determined metals such as $\mathrm{Pb}, \mathrm{Co}, \mathrm{Cd}, \mathrm{Cr}, \mathrm{Fe}, \mathrm{Cu}, \mathrm{Mn}$, and $\mathrm{Zn}$ in farmed white shrimp analysing its muscle, liver and shell (Table 1). Only 5 ( $\mathrm{Cr}, \mathrm{Cu}, \mathrm{Fe}, \mathrm{Mn}$, and $\mathrm{Zn}$ ) of the 8 metals were found in all matrices with average concentrations of $22.8,60.5,80.2,8.3$, and $111.7 \mathrm{mg} \mathrm{kg}^{-1}$, respectively for the 5 metals found [53]. Wu and Yang [53] also found that the muscle was the main accumulation site for $\mathrm{Zn}\left(171.6 \mathrm{mg} \mathrm{kg}^{-1}\right)$ in comparison to shell (51.8 $\mathrm{mg} \mathrm{kg}^{-1}$ ) and liver $\left(111.7 \mathrm{mg} \mathrm{kg}^{-1}\right)$. On the other hand, Cd was observed only in liver tissue at $3.30 \pm 1.29 \mathrm{mg} \mathrm{kg}^{-1}$ and $\mathrm{Pb}$ could not be detected [53].

Regarding the derivatization step, it is required to enhance the analytical response of the compounds, that is, increasing their volatility, decreasing their polarity, thus improving their detection, which means that a more long time is need to the complete analysis. The silylation is commonly carried out to obtain trimethylsilyl derivatives and BSFTA is the most employed. However, according to the literature in this review, the derivatization step was only used in one work [21], where PAH and alkylphenols were determined by GC-MS and previously extracted with EtOAc.

The surface sediments of aquaculture farms are also studied for the presence of contaminants but in a less extent than aquaculture fish and shellfish, as shown in Table 1. Contaminants tend to rapidly adsorb to sediment particles and can be redistributed and reintroduced back to the food chain constituting an environmental concern, mainly in aquaculture farms, where foodstuffs are produced, and they can be deposited in the fatty tissues of aquatic animals with possible hazardous consequences to human beings. For example, Wang et al. [57] and Retnam et al. [28] have determined 16 priority pollutants PAH with GC-MS, Yu et al. [59] have reported the determination of nitrofurans and their metabolites with HPLC-DAD, Wang et al. [56] determined HCH and DDT with GC-MS, and Liu et al. [40] have determined steroids with rapid resolution liquid chromatography-tandem MS (RRLC-MS/MS), in surface sediments of aquaculture farms for all works, as shown in Table 1. Wang et al. [57] found moderately high PAH levels in Chinese surface sediments in a range of 123-947 $\mathrm{ng} \mathrm{g}^{-1}$ (mean of $450 \mathrm{ng} \mathrm{g}^{-1}$ ) and referred that the sum of the seven carcinogenic PAH in aquaculture surface sediments, that is benz[a]anthracene, chrysene, benzo[a]pyrene, benzo[b]fluoranthene, benzo[k]fluoranthene, indeno[1,2,3-cd]pyrene, and dibenz[a,h]anthracene, ranged from 50.9 to $383 \mathrm{ng} \mathrm{g}^{-1}$ (mean of $166 \mathrm{ng} \mathrm{g}^{-1}$ ) which is higher than maximum levels permitted in foodstuffs (2.0-10.0 $\left.\mathrm{ng} \mathrm{g}^{-1}\right)$ from EC 1881/2006 [14], since limits for sediments not exist. In the work of Retnam et al. [28], where the characterization of PAH in aquaculture sediments from Malaysia was reported, higher levels of PAH were found (20-1841 $\mathrm{ng} \mathrm{g}^{-1}$ with a mean of $363 \mathrm{ng} \mathrm{g}^{-1}$ ) in comparison to the work of Wang et al. [57]; 
PAH are dominated by high molecular weight PAH indicating pyrogenic sources. Retnam et al. [28] used chemometric techniques for source apportionment of PAH (absolute principle component scores and multiple linear regression) to determine the percent contribution of different PAH sources. Retnam et al. [28] found that the first of the three factors responsible for $89 \%$ of the total variation of PAH in aquaculture sediments is responsible to $41.1 \%$ of the total variation and heavily loaded with 4- and 6-ring PAH including fluoranthene, pyrene, benzo[a]anthracene, benzo[b,k]fluoranthene, benzo[a]pyrene, indeno[1,2,3-cd]pyrene, dibenzo[a,h]anthracene, and benzo[g,h,i]perylene), which is the typical composition of vehicular combustion. The second factor is responsible to $24.4 \%$ of the total variance involving 2-ring PAH (naphthalene) and alkylated naphthalene which are commonly verified in uncombusted petroleum, also with moderate loading of acenaphthylene, acenaphthene, fluorene, phenanthrene, anthracene, suggesting a combustion source, and the third factor is responsible for $23.5 \%$ of the total variance and dominated by alkylated phenanthrene and retene, which are associated with coal combustion [28]. Thus, Retnam et al. [28] concluded that the major contribution of the PAH sources in surface sediments came from vehicle emissions (54\%), oil combustion (37\%), and biomass combustion (9\%).

Liu et al. [40] have determined 24 steroids (androgens, glucocorticoids, and progestagens) in three matrices of marine aquaculture farms, that is, seawater, sediments, and biota samples (fish, molluscs, crabs, and shrimps) through RRLC-MS/MS (Table 1). It has been verified that steroids have become a public concern in aquatic environment due to their endocrinedisrupting effects such as decreased fertility, feminization, and hermaphroditism on aquatic organisms, even at very low concentrations of approximately $1 \mathrm{ng} \mathrm{\textrm {L } ^ { - 1 }}$ [40], occurring in aquatic environment from the excretion (faeces and urine) of humans, livestock, and aquatic organisms. Concentrations ranging from $<0.1$ (testosterone) to $40 \mathrm{ng} \mathrm{L}^{-1}$ (prednisolone, a synthetic glucocorticoid), from 0.1 (4-androstene-3,17-dione) to $2.4 \mathrm{ng} \mathrm{g}^{-1}$ (progesterone), and from $<0.1$ (testosterone) to $560 \mathrm{ng} \mathrm{g}^{-1}$ (cortisol) were detected in seawater (for 10 steroids), sediments (for 9 steroids), and biota samples (for 15 steroids), respectively [40].

Other works also considered the analysis of contaminants in waters from aquaculture sites, as shown in Table 1. For example, Rodríguez et al. [60] have used an online SPE coupled to HPLC-FLD to simultaneously determine antibiotics (enrofloxacin, ciprofloxacin, norfloxacin, levofloxacin, danofloxacin, and sarafloxacin) in aquaculture water samples, with good recoveries (>91\%). The online SPE system was based on molecularly imprinted microspherical polymer particles, which constitutes innovative, reliable, and robust sorbents in the extraction system. In addition, in online configurations, the extracted species are 
usually transferred from the SPE column to the analytical column by elution with the LC mobile phase, which constitutes an advantage of this analytical approach. Rodríguez et al. [60] verified that molecularly imprinted polymer SPE can be reused for more than 200 assays without losing their concentration efficiency, facilitating the automation of the online preconcentration system. Yu et al. [59] have detected nitrofurans and their metabolites in water from aquaculture ponds using HPLC-DAD and LC-MS/MS, respectively (Table 1). The respective chromatograms are shown in Figure 3, where no interfering peaks were found. The detection of nitrofurans in the waters required no extraction except centrifugation and filtration (centrifuged for $10 \mathrm{~min}$ at $8000 \times \mathrm{g}$ and then filtered through $0.45-\mu \mathrm{m}$-pore nylon filters). Thus, such simple pretreatment required before HPLC analysis constitutes an advantage to the use of HPLC for determination of nitrofurans in the waters and it is suitable because it was simple and rapid to perform [59].

\section{< Figure 3 >}

Cirillo et al. [8] reported the determination of various contaminants on water samples from rainbow trout aquaculture taking into account the procedures reported in EPA methods, that is, EPA 1668 for PCB detection [68], EPA 1613 for dioxins detection [69], and EPA 200.7 for $\mathrm{Pb}$ and $\mathrm{Cd}$ detections [70]. Such procedures consist in SPE for the extraction of PCB and dioxins, and they are determined by HRGC-HRMS; the metals were determined by ICP-AES (Table 1). According to the results obtained, Cirillo et al. [8] referred that non dioxin-likePCB, dioxin-like PCB and dioxins in breeding waters were never found at detectable levels ( $<0.1 \mathrm{pg} \mathrm{g}^{-1}$ for organic compounds, and $0.06 \mu \mathrm{g} \mathrm{g}^{-1}$ for $\mathrm{Pb}$ and $0.0009 \mu \mathrm{g} \mathrm{g}^{-1}$ for $\mathrm{Cd}$ ). Recently, Liu et al. [40] used the RRLC-MS/MS for the determination of steroids in aquaculture waters (Table 1) reporting the detection of 10 steroids with concentrations ranging from $<0.1$ (testosterone) to $40 \mathrm{ng} \mathrm{L}^{-1}$ (prednisolone). Liu et al. [40] referred that such concentrations are similar to the levels detected in the effluents from wastewater treatment plants or surface water reported in previous works of the same research team $[71 ; 72]$. Recently, biological warning systems have found wide application in the monitoring of water quality and they are adapted to fish farming [73]. This approach can be useful as an online continuous monitoring practice in order to verify the absence of unknown harmful substances and to non-invasively monitor health, quality and welfare [73]. Thus, the development of 
online alert systems is an important route for the improvement of aquatic environment such as in aquaculture facilities.

\section{Quality assurance and quality control}

The representativeness is important for the reliability of analytical information. A representative sample is a sample that is typical of the parent material for the characteristic under inspection. For the aquaculture samples taken into consideration in this review, they are associated with a very dynamic system, since the sample at any instant is characteristic of the sampling moment and in a particular location. Thus, the sampling plan should be well defined in order to identify the exact geographic location and time of sampling as well as the number of samples collected and methodology for sampling. For example, Pinto et al. [41] collected the aquaculture samples (fish) during three time intervals over the year, that is, winter (November to February), spring and autumn (March, April, May, and October), and summer (June to September). The 40 fish samples were measured and weighted and $200 \mathrm{~g}$ (wet weight) of the organisms were selected, homogenised, and lyophilised for subsequent cleanup and extraction of PCB. Perugini et al. [34] proposed a longer sampling plan: the rainbow trout (67 exemplars) were sampled during 5 years and collected directly in trout farms, and all trout were of a commercial size (29-32 cm and 270-300 g). Another example of sampling plan is involved in the work of Cirillo et al. [8], where rainbow trout were collected in a fish farm (150000 specimens with mean weight of $35 \mathrm{~g}$ ) characterized by scarce seasonal variations in chemical and physical parameters of water during all the year. Thus, the trout were collected over January and July 2010 , where mean water temperature of farming was $13^{\circ} \mathrm{C}$ with daily variation of $4^{\circ} \mathrm{C}$, oxygen content of $7 \mathrm{ppm}$ with daily variation of $3 \mathrm{ppm}$ and $\mathrm{pH}$ of 7.7-7.8.

For the validation of an analytical method, an analytical protocol should be designed starting at the sampling stage and keeping control strategies in place at all the following sequential steps, that is, sample preparation, analyte extraction, and analyte determination. Each interconnected step of the whole analytical protocol can contribute to the uncertainty of the method. Figure 4 shows a schematic representation of the analytical method within the analytical procedure and respective sequential steps.

\section{$<$ Figure 4 >}


The validation protocol for the applied analytical techniques is done by evaluating precision, trueness, selectivity, specificity, recovery, limit of detection and limit of quantitation, and sensitivity. Such analytical performance characteristics are established in the European Commission Decision 2002/657/EC and they are required for the validation of analytical methods used for the determination of environmental contaminants [65], thus defining the respective quality assurance. For the quality control, the use of validated or standardized methods is crucial for the comparison of results of the applied analytical technique in order to demonstrate the fitness-for-purpose of an analytical method.

The precision is evaluated through the repeatability and reproducibility of the analytical response by estimation of the relative standard deviation or coefficient of variation. As a characteristic related to the random error of a measurement system, RSD between $2 \%$ and $20 \%$ for repeatability of the method and between $5 \%$ and $17 \%$ for reproducibility were found in the literature revised using up to 5 concentration levels and 3-5 repeats per concentration, which indicates acceptable variability for the various analytical techniques reported. The trueness is expressed in terms of bias, which is the difference between the mean value determined for the analyte of interest and the accepted true value or known level actually present [74]. For the estimation of trueness, certified reference materials (pure substances, standard solutions or matrix certified reference materials) can be used. In some works, no certified reference materials are available and the blank samples spiked with known amounts of analyte of interest (quality control samples) are then acceptable. In these cases, the recovery is calculated as the percentage of the measured spike of the blank control or the amount of spike added to the sample [74]. For example, Cirillo et al. [8] found recovery rates of $97 \pm 6 \%$ and $83 \pm 7 \%$ for $\mathrm{Pb}$ and $\mathrm{Cd}$ in a certified fish standard matrix was processed and analysed between trout samples. As shown in the Section 4 and Table 1, the calculation of recoveries was the most used for the estimation of the trueness of the different analytical techniques, which are acceptable for the majority of works, indicating lower bias affected to the analytical method. Pinto et al. [41] used GC-MS to confirm the PCB quantification found by GC-ECD. In GC-MS, the internal standard solution (PCB 209) was added to the extract before injecting. Fernandes et al. [21] refers that the quantitation of PCB and OCP by GCECD was performed using an external standard calibration mixture of PCB congeners and Russel et al. [55] reported the addition of internal standards (2,4-dichlorobenzyl alkyl hexyl ether with $\mathrm{C}_{6}$ and $\mathrm{C}_{16}$ alkyl chains) to the extract before GC-ECD analysis. In another work [31], a 7-points calibration (1-100 $\left.\mu \mathrm{g} \mathrm{L}^{-1}\right)$ was used to quantify metal concentration through ICP-MS (Table 1). Coefficients of variation $(n=5)$ varied between $0.5 \%$ and $2 \%$. The 
precision and accuracy of each metal concentration measurement, determined through repeated analysis of certified reference materials, using In as internal standard, were 1-4\%. Procedural blanks always accounted for less than $1 \%$ of the total metal concentrations in samples [31]. According to Decision 2002/675/EC [65], the use of internal standards in MS methods is mandatory to fulfill the criteria of identification that was based on the relative retention time related to the internal standard. For all calculations the peak areas of both the analytes and corresponding internal standard were measured and the analyte/internal standard area ratios determined [65].

Freitas et al. [45] demonstrated the selectivity and specificity by analysing 20 blank samples of gilthead sea bream from different origins to exclude the presence of any possible interference in the identification of the target antibiotics. The identification of all compounds was effective in all spiked samples without any false-negative result.

As shown in Table 1, the majority of the works reported the determination of LOD, through the usual definition of the concentration of the analyte yielding a signal equivalent to three times the standard deviation of the reagent blank signal, and in a less extent the LOQ.

\section{Conclusions and future perspectives}

Although the aquaculture production has been increased both at a global state and in European countries, constituting a valuable food supply and also promoting the economic development, potential contamination of aquaculture products by animal feed, veterinary drugs, and/or neighbouring environmental conditions of aquaculture sites still remains. Some works reported levels of contaminants higher than those established in global or European legislations, which should arouse further scientific attention. Toxic substances generally belonging to the class of veterinary drugs still applied in fish feed for the prevention of diseases, having the ability to bioaccumulate in fish organisms, thus interfering in the food safety of aquaculture products.

Regarding the whole analytical protocol for the analysis of aquaculture contaminants, some conclusions can be withdrawn. One of the main limitations of the sample preparation is the long time required for the fast, efficient and reliable extraction of target analytes (contaminants) and clean-up of the sample. Research is nowadays directed to the automation of procedures, also using green analytical extractions and advanced sorbents in the clean-up step for the enhanced determination of contaminants from environmental samples. The miniaturization is also a strategy employed in sample preparation in order to minimize or 
eliminate the use of toxic solvents and reagents. Concerning the analytical techniques employed to detect and determine contaminants in aquaculture, the multi-residue and multiclass determination is very sought due to the higher analysis throughput and LC-MS/MS was the most used technique for such simultaneous determination mainly due to its improved resolution.

Research tasks for future aquaculture development should considered the fast monitoring of trace contaminants in tissues of fish, crustaceans and molluscs in order to detect levels which could represent a risk for human health. The development of online alert systems mainly in aquaculture sites can be a valuable technological advance in order to early detect any chemical or biological perturbation in produced organisms.

\section{Acknowledgments}

This work was funded by Portuguese Science Foundation (FCT) through scholarships (ref. SFRH/BPD/95961/2013, SFRH/BD/84524/2012, and SFRH/BPD/73781/2010) under QRENPOPH funds, co-financed by the European Social Fund and Portuguese National Funds from MEC. This work was also funded by national funds through FCT/MEC (PIDDAC) under project IF/00407/2013/CP1162/CT0023 and by FCT under project UID/AMB/50017/2013.

\section{References}

[1] $\operatorname{COM}(2012)$ 494. Communication from the Commission to the European Parliament, the Council, the European Economic and Social Committee and the Committee of the Regions.

Blue Growth: opportunities for marine and maritime sustainable growth. Brussels, 13.9.2012. Available at:

http://eur-lex.europa.eu/LexUriServ/LexUriServ.do?uri=COM:2012:0494:FIN:EN:PDF

[2] Council Directive 2006/88/EC on animal health requirements for aquaculture animals and products thereof, and on the prevention and control of certain diseases in aquatic animals. Official Journal of the European Union L 328, of 24 October 2006. Available at: http://eur-lex.europa.eu/legal-content/EN/TXT/PDF/?uri=CELEX:32006L0088\&from=EN

[3] NOAA fisheries. What is Aquaculture? National Oceanic and Atmospheric Administration. Available at:

http://www.nmfs.noaa.gov/aquaculture/what_is_aquaculture.html 
[4] FAO 2014. The State of World Fisheries and Aquaculture Opportunities and challenges. Food and Agriculture Organization of the United Nations. Rome, 2014. Available at: http://www.fao.org/3/a-i3720e.pdf

[5] JRC 2013. Scientific, Technical and Economic Committee for Fisheries (STECF) - The Economic Performance Report on the EU Aquaculture sector (STECF-13-29). 2013. Publications Office of the European Union, Luxembourg, EUR 26336 EN, JRC 86671, pp. 383. Available at: http://stecf.jrc.ec.europa.eu/documents/43805/622206/2013-12_STECF+13-29++Aquaculture+economics_JRC86671.pdf

[6] P. Cretì, F. Trinchella, R. Scudiero, Heavy metal bioaccumulation and metallothionein content in tissues of the sea bream Sparus aurata from three different fish farming systems, Environ. Monit. Assess. 165 (2010) 321-329.

[7] A.G.J. Tacon, M. Metian, Aquaculture feed and food safety. The role of the Food and Agriculture Organization and the Codex Alimentarius, Ann. N.Y. Acad. Sci. 1140 (2008) $50-59$.

[8] T. Cirillo, E. Fasano, F. Esposito, M. Amorena, R.A. Cocchieri, Occurrence of NDLPCBs, DL-PCBs, PCDD/Fs, lead and cadmium in feed and in rainbow trout (Oncorhynchus mykiss) farmed in Italy, Food Addit. Contam. A 31 (2014) 276-287.

[9] H.-Y. Yu, B.-Z. Zhang, J.P. Giesyf, E.Y. Zeng, Persistent halogenated compounds in aquaculture environments of South China: Implications for global consumers' health risk via fish consumption, Environ. Int. 37 (2011) 1190-1195.

[10] ESFA, Opinion of the scientific panel on contaminants in the food chain on a request from the European Parliament related to the safety assessment of wild and farmed fish. EFSA J. 236 (2005) 1-118.

[11] T. Håstein, B. Hjeltnes, A. Lillehau, J.U. Skare, M. Berntssen, A.K. Lundebye, Food safety hazards that occur during the production stage: challenges for fish farming and the fishing industry, Rev. Sci. Tech. Off. Int. Epiz. 25 (2006) 607-625.

[12] D.W. Cole, R. Cole, S.J. Gaydos, J. Gray, G. Hyland, M.L. Jacques, N. Powell-Dunford, C. Sawhney, W.W. Au, Aquaculture: environmental, toxicological, and health issues, Int. J. Hyg. Environ. Health 212 (2009) 369-377.

[13] M. Farré, L. Kantiania, M. Petrovic, S. Pérez, D. Barceló, Achievements and future trends in the analysis of emerging organic contaminants in environmental samples by mass spectrometry and bioanalytical techniques, J. Chromatogr. A 1259 (2012) 86-99. 
[14] Commission Regulation EC 1881/2006 setting maximum levels for certain contaminants in foodstuffs. Official Journal of the European Union L 364, of 19 December 2006. Available at:

http://eur-lex.europa.eu/legal-content/EN/TXT/PDF/?uri=CELEX:32006R1881\&from=en

[15] Commission Regulation EU 1259/2011 amending Regulation (EC) No 1881/2006 as regards maximum levels for dioxins, dioxin-like PCBs and non dioxin-like PCBs in foodstuffs. Official Journal of the European Union L 320, of 2 December 2011. Available at:

http://eur-

lex.europa.eu/LexUriServ/LexUriServ.do?uri=OJ:L:2011:320:0018:0023:EN:PDF

[16] Commission Regulation EU 37/2010 on pharmacologically active substances and their classification regarding maximum residue limits in foodstuffs of animal origin. Official Journal of the European Union L 15, of 22 December 2009. Available at: http://ec.europa.eu/health/files/eudralex/vol-5/reg_2010_37/reg_2010_37_en.pdf

[17] Council Directive 86/363/EEC on the fixing of maximum levels for pesticide residues in and on foodstuffs of animal origin. Official Journal of the European Communities L 221, of 24 July 1986. Available at:

http://eur-lex.europa.eu/legal-content/EN/TXT/PDF/?uri=CELEX:31986L0363\&from=en

[18] M. Muñoz de Toro, H.R. Beldoménico, S.R. Garcia, C. Stoker, J.J. de Jesús, P.M. Beldoménico, J.G. Ramos, E.H. Luque, Organochlorine levels in adipose tissue of woman from a littoral region of Argentina, Environ. Res. 102 (2006) 107-112.

[19] H. Tsukino, T. Hanaoka, H. Sasaki, H. Motoyama, M. Hirosima, T. Tanaka, M. Kabuto, W. Turner, D.G. Patterson, L. Needham, S. Tsugane, Fish intake and serum levels of organochlorines among Japanese women, Sci. Total Environ. 359 (2006) 90-100.

[20] M. Someya, M. Ohtake, T. Kunisue, A. Subramanian, S. Takahashi, P. Chakraborty, R. Ramachandran, S. Tanabe, Persistent organic pollutants in breast milk of mothers residing around an open dumping site in Kolkata, India: specific dioxin-like PCB levels and fish as a potential source, Environ. Int. 36 (2010) 27-35.

[21] D. Fernandes, S. Zanuy, M.J. Bebianno, C. Porte, Chemical and biochemical tools to assess pollution exposure in cultured fish, Environ. Pollut. 152 (2008) 138-146.

[22] K. Grigorakis, G. Rigos, Aquaculture effects on environmental and public welfare - The case of Mediterranean mariculture, Chemosphere 855 (2011) 899-919.

[23] T. Watanabe, K. Viswanath, S. Satoh, Trace minerals in fish nutrition, Aquaculture 151 (1997) 185-207. 
[24] C.G.J. van Bussel, J.P. Schroeder, L. Mahlmann, C. Schulz, Aquatic accumulation of dietary metals ( $\mathrm{Fe}, \mathrm{Zn}, \mathrm{Cu}, \mathrm{Co}, \mathrm{Mn}$ ) in recirculating aquaculture systems (RAS) changes body composition but not performance and health of juvenile turbot (Psetta maxima), Aquacult. Eng. 61 (2014) 35-42.

[25] S. Díez, Human health effects of methylmercury exposure, in: D.M. Whitacre (Ed.), Reviews of environmental contamination and toxicology, Springer-Verlag New York, 2009, pp. 111.

[26] USEPA, 2015. Priority pollutants. Available at:

http://water.epa.gov/scitech/methods/cwa/pollutants.cfm?_ga=1.164041663.1036484129.1 428664371

[27] J. Nácher-Mestre, R. Serrano, T. Portolés-Nicolau, F. Hernández, L. Benedito-Palos, J. Pérez-Sánchez, A reliable analytical approach based on gas chromatography coupled to triple quadrupole and time-of-flight mass analyzers for the determination and confirmation of polycyclic aromatic hydrocarbons in complex matrices from aquaculture activities, Rapid Commun. Mass Spectrom. 23 (2009) 2075-2086.

[28] A. Retnam, M.P. Zakaria, H. Juahir, A.Z. Aris, M.A. Zali, M.F. Kasim, Chemometric techniques in distribution, characterisation and source apportionment of polycyclic aromatic hydrocarbons (PAHs) in aquaculture sediments in Malaysia, Mar. Pollut. Bull. 69 (2013) 55-66.

[29] R. Rodil, A.M. Carro, R.A. Lorenzo, R. Cela, Multicriteria optimisation of a simultaneous supercritical fluid extraction and clean-up procedure for the determination of persistent organohalogenated pollutants in aquaculture samples, Chemosphere 67 (2008) $1453-1462$.

[30] S.L. Blanco, A. Martínez, C. Porro, J.M. Vieites, Dietary uptake of polybrominated diphenyl ethers (PBDEs), occurrence and profiles, in aquacultured turbots (Psetta maxima) from Galicia, Spain, Chemosphere 85 (2011) 441-447.

[31] M. Ferreira, M. Caetano, P. Antunes, J. Costa, O. Gil, N. Bandarra, P. Pousão-Ferreira, C. Vale, M.A. Reis-Henriques, Assessment of contaminants and biomarkers of exposure in wild and farmed seabass, Ecotoxicol. Environ. Saf. 73 (2010) 579-588.

[32] H.-Y. Yu, Y. Guo, L.-J. Bao, Y.-W. Qiu, E. Y. Zeng, Persistent halogenated compounds in two typical marine aquaculture zones of South China, Mar. Pollut. Bull. 63 (2011) 572577.

[33] EFSA, EFSA Scientific Report. Results of the monitoring of non dioxin-like PCBs in food and feed, EFSA J. 8 (2010) 1-35. 
[34] M. Perugini, M. Manera, T. Tavoloni, C. Lestingi, I. Pecorelli, A. Piersanti, Temporal trends of PCBs in feed and dietary influence in farmed rainbow trout (Oncorhynchus mykiss), Food Chem. 141 (2013) 2321-2327.

[35] G.O. Conti, C. Copat, Z. Wang, P. D'Agati, A. Cristaldi, M. Ferrante, Determination of illegal antimicrobials in aquaculture feed and fish: an ELISA study, Food Control 50 (2015) 937-941.

[36] H.T.T. Thuy, L.P. Nga, T.T.C. Loan, Antibiotic contaminants in coastal wetlands from Vietnamese shrimp farming, Environ. Sci. Pollut. Res. 18 (2011) 835-841.

[37] I. Karunasagar. Minimising antimicrobial use in aquaculture and improving food safety, in: J. Ryder, L. Ababouch, M. Balaban (Eds) Second International Congress on Seafood Technology on Sustainable, Innovative and Healthy Seafood. FAO/The University of Alaska. 10-13 May 2010, Anchorage, United States of America. FAO Fisheries and Aquaculture Proceedings. No. 22. Rome, FAO. 2012, pp. 238. Available at: http://www.fao.org/docrep/015/i2534e/i2534e.pdf

[38] Q. Zheng, R. Zhang, Y. Wang, X. Pan, J. Tang, G. Zhang, Occurrence and distribution of antibiotics in the Beibu Gulf, China: Impacts of river discharge and aquaculture activities, Mar. Environ. Res. 78 (2012) 26-33.

[39] D. Klinger, R. Naylor, Searching for solutions in aquaculture: charting a sustainable course. Annu. Rev. Environ. Resour. 37 (2012) 247-276.

[40] S. Liu, H. Chen, X.-R. Xu, S.-S. Liu, K.-F. Su, J.-L. Zhao, G.-G. Ying, Steroids in marine aquaculture farms surrounding Hailing Island, South China: occurrence, bioconcentration, and human dietary exposure, Sci. Total Environ. 502 (2015) 400-407.

[41] B. Pinto, S.L. Garritano, R. Cristofani, G. Ortaggi, A. Giuliano, R. Amodio-Cocchieri, T. Cirillo, M. de Giusti, A. Boccia, D. Reali, Monitoring of polychlorinated biphenyl contamination and estrogenic activity in water, commercial feed and farmed seafood, Environ. Monit. Assess. 144 (2008) 445-453.

[42] S.L. Blanco, C. Sobrado, C. Quintela, S. Cabaleiro, J.C. González, J.M. Vieites, Dietary uptake of dioxins (PCDD/PCDFs) and dioxin-like PCBs in Spanish aquacultured turbot (Psetta maxima), Food Addit. Contam. 24 (2008) 421-428.

[43] R. Serrano, M. Barreda, M.A. Blanes, Investigating the presence of organochlorine pesticides and polychlorinated biphenyls in wild and farmed gilthead sea bream (Sparus aurata) from the Western Mediterranean sea, Mar. Pollut. Bull. 56 (2008) 963-972. 
[44] J.N. Pearce, B.G. Burns, J.M. van de Riet, M.D. Casey, R.A. Potter, Determination of fluoroquinolones in aquaculture products by ultra-performance liquid chromatographytandem mass spectrometry (UPLC-MS/MS), Food Addit. Contam. A 26 (2009) 39-46.

[45] A. Freitas, S. Leston, J. Rosa, M.C. Castilho, J. Barbosa, P. Rema, M.Â. Pardal, F. Ramos, Multi-residue and multi-class determination of antibiotics in gilthead sea bream (Sparus aurata) by ultra high-performance liquid chromatography-tandem mass spectrometry, Food Addit. Contam. A 31 (2014) 817-826.

[46] E.N. Evaggelopoulou, V.F. Samanidou, B. Michaelidis, I. Papadoyannis, Development and validation of an LC-DAD method for the routine Analysis of residual quinolones in fish edible tissue and fish feed. Application to farmed Gilthead sea bream following dietary administration, J. Liquid Chromatogr. Rel. Technol. 37 (2014) 2142-2161.

[47] E.L.E. Jester, A. Abraham, Y. Wang, K.R. El Said, S.M. Plakas, Performance evaluation of commercial ELISA kits for screening of furazolidone and furaltadone residues in fish, Food Chem. 145 (2014) 593-598.

[48] A. Gadaj, V. di Lullo, H. Cantwell, M. McCormack, A. Furey, M. Danaher, Determination of nitroimidazole residues in aquaculture tissue using ultra high performance liquid chromatography coupled to tandem mass spectrometry, J. Chromatogr. B 960 (2014) 105-115.

[49] J.A.R. Paschoal, F.G.R. Reyes, S. Rath, Determination of quinolone residues in tilapias (Orechromis niloticus) by HPLC-FLD and LC-MS/MS QToF, Food Addit. Contam. A 26 (2009) 1331-1340.

[50] M.E. Dasenaki, N.S. Thomaidis, Multi-residue determination of seventeen sulfonamides and five tetracyclines in fish tissue using a multi-stage LC-ESI-MS/MS approach based on advanced mass spectrometric techniques, Anal. Chim. Acta 672 (2010) 93-102.

[51] H. Li, P.J. Kiljak, Development of a quantitative multiclass/multiresidue method for 21 veterinary drugs in shrimp, J. AOAC Int. 94 (2011) 394-406.

[52] M. Gbylik, A. Posyniak, K. Mitrowska, T. Bladek, J. Zmudzki, Multi-residue determination of antibiotics in fish by liquid chromatography-tandem mass spectrometry, Food Addit. Contam. A 30 (2013) 940-948.

[53] X.-Y. Wu, Y.-F. Yang, Heavy metal (Pb, Co, Cd, Cr, Cu, Fe, Mn and Zn) concentrations in harvest-size white shrimp Litopenaeus vannamei tissues from aquaculture and wild source, J. Food Compos. Anal. 24 (2011) 62-65. 
[54] D. Jiang, Z. Hu, F. Liu, R. Zhang, B. Duo, J. Fu, Y. Cui, M. Li, Heavy metals levels in fish from aquaculture farms and risk assessment in Lhasa, Tibetan Autonomous Region of China, Ecotoxicology 23 (2014) 577-583.

[55] M. Russell, C.D. Robinson, P. Walsham, L. Webster, C.F. Moffat, Persistent organic pollutants and trace metals in sediments close to Scottish marine fish farms, Aquaculture 319 (2011) 262-271.

[56] H.-S. Wang, Z.-J. Chen, Z. Cheng, J. Du, Y.-B. Man, H.-M. Leung, J. P. Giesy, C. K.C. Wong, M.-H. Wong, Aquaculture-derived enrichment of hexachlorocyclohexanes (HCHs) and dichlorodiphenyltrichloroethanes (DDTs) in coastal sediments of Hong Kong and adjacent mainland China, Sci. Total Environ. 466 (2014) 214-220.

[57] H.-S. Wang, P. Liang, Y. Kang, D.-D. Shao, G. J. Zheng, S.-C. Wu, C. K.C. Wong, M. H. Wong, Enrichment of polycyclic aromatic hydrocarbons (PAHs) in mariculture sediments of Hong Kong, Environ. Pollut. 158 (2010) 3298-3308.

[58] A. Specchiulli, M. Renzi, G. Perra, L. Cilenti, T. Scirocco, M. Florio, S. Focardi, P. Breber, S. Focardi, Distribution and sources of polycyclic aromatic hydrocarbons (PAHs) in surface sediments of some Italian lagoons exploited for aquaculture and fishing activities, Int. J. Environ. Anal. Chem. 91 (2011) 367-386.

[59] W.-H. Yu, T.-S. Chin, H.-T. Lai, Detection of nitrofurans and their metabolites in pond water and sediments by liquid chromatography (LC)-photodiode array detection and LCion spray tandem mass spectrometry, Int. Biodeter. Biodegrad. 85 (2013) 517-526.

[60] E. Rodríguez, F. Navarro-Villoslada, E. Benito-Peña, M.D. Marazuela, M.C. MorenoBondi, Multiresidue determination of ultratrace levels of fluoroquinolone antimicrobials in drinking and aquaculture water samples by automated online molecularly imprinted solid phase extraction and liquid chromatography, Anal. Chem. 83 (2011) 2046-2055.

[61] K. Duarte, C.I.L. Justino, A.M. Gomes, T.A.P. Rocha-Santos, A.C. Duarte, Green analytical methodologies for preparation of extracts and analysis of bioactive compounds, in: T.A.P. Rocha-Santos, A.C. Duarte (Eds.), Comprehensive Analytical Chemistry Book Series, Elsevier, Amsterdam, 2014, pp. 79 (Chapter 4).

[62] M. de la Guardia, S. Armenta, Green Analytical Chemistry, volume 57: theory and practice. Comprehensive Analytical Chemistry, Elsevier, 2011.

[63] S. Armenta, S. Garrigues, M. de la Guardia, Green Analyrtical Chemistry, Trends Anal. Chem. 27 (2008) 497-511. 
[64] B. Huerta, S. Rodríguez-Mozaz, D. Barceló, Pharmaceuticals in biota in the aquatic environment: analytical methods and environmental implications, Anal. Bioanal. Chem. 404 (2012) 2611-2624.

[65] Commission Decision 2002/657/EC implementing Council Directive 96/23/EC concerning the performance of analytical methods and the interpretation of results. Official Journal of the European Communities L 221, of 12 August 2002. Available at: http://eur-lex.europa.eu/legal-content/EN/TXT/PDF/?uri=CELEX:32002D0657\&from=EN

[66] S.D. Richardson, Environmental mass spectrometry: emerging contaminants and current issues, Anal. Chem. 84 (2012) 747-778.

[67] FAO 1983. Compilation of legal limits for hazardous substances in fish and fishery products. FAO Fisheries Circular No. 464, Rome, pp. 95. Available at: http://www.fao.org/docrep/014/q5114e/q5114e.pdf

[68] EPA 1668, Chlorinated biphenyl congeners in water, soil, sediment biosolids and tissue by HRGC/HRMS: Method 1668 Rev. B, November 2008. Washington: US Environmental Protection Agency Office of Water Engineering and Analysis Division.

[69] EPA 1613, Tetra-through octa-chlorinated dioxins and furans by isotope dilution HRGC/HRMS: Method 1613 Rev. B, October 1994. Washington: US Environmental Protection Agency Office of Water Engineering and Analysis Division.

[70] EPA. 1991, Method 200.7 - Methods for the Determination of Metals in Environmental Samples, June 1991, NTIS Publication 91-231498. Washington: US Environmental Protection Agency.

[71] H. Chang, Y. Wan, S. Wu, Z. Fan, J.Y. Hu, Occurrence of androgens and progestogens in wastewater treatment plants and receiving river waters: comparison to estrogens, Water Res. 45 (2011) 732-740.

[72] S. Liu, G.G. Ying, J.L. Zhao, F. Chen, B. Yang, L.J. Zhou, H.J. Lai, Trace analysis of 28 steroids in surface water, wastewater and sludge samples by rapid resolution liquid chromatography-electrospray ionization tandem mass spectrometry, J. Chromatogr. A 1218 (2011) 1367-1378.

[73] H. Eguiraun, U. Izagirre, I. Martinez, A paradigm shift in safe seafood production: from contaminant detection to fish monitoring - application of biological warning systems to aquaculture, Trends Food Sci. Tech. 43 (2015) 104-113.

[74] I. Taverniers, M.D. Loose, E.V. Bockstaele, Trends in quality in the analytical laboratory. II. Analytical method validation and quality assurance, Trends Anal. Chem. 23 (2004) 535-552. 


\section{Figure Captions}

Figure 1 Ion chromatograms for shrimp tissue for the 21 drugs and the internal standard $\left(\mathrm{NOR}_{-} \mathrm{d}_{5}\right.$ ) (Li and Kijak [51]. Copyright 2011 by AOAC INTERNATIONAL. Permission is granted for a reprint of Figure 2). Sulfadiazine (SDZ), sulfamerazine (SMR), sulfamethazine (SMZ), sulfachloropyridazine (SCP), sulfadimethoxine (SDM), sulfaquinoxaline (SQX), norfloxacin (NOR), ciprofloxacin (CIPRO) hydrochloride monohydrate, enrofloxacin (ENR), sarafloxacin (SAR) hydrochloride trihydrate, difloxacin (DIF) hydrochloride, oxolinic acid (OXO), nalidixic acid (NAL), flumequine (FLU), oxytetracycline (OTC) dihydrate, tetracycline (TC) hydrochloride, chlortetracycline (CTC) hydrochloride, leucogentian violet (LGV), leucomalachite green (LMG), and malachite green (MG) oxalate, gentian violet (GV) chloride.

Figure 2 Cadmium (a) and lead (b) content in sea bream tissues from three different fish farming systems. Each value is expressed as mean \pm S.D $(n=8)$. Farmed-1 are fish specimens from intensive breeding system, farmed-2 fish from semi-intensive, and farmed-3 fish from extensive breeding system (from Cretì et al. [6], reproduced with permission from Springer).

Figure 3 Chromatograms from a) HPLC-DAD for the four nitrofurans in aquaculture pond waters [furaltadone (FTD), furazolidone (FZD), nitrofurantoin (NFT), and nitrofurazone (NFZ)]; b) LC-MS/MS for the four nitrofurans metabolites in aquaculture pond waters [3amino-5-morpholinomethyl-2-oxazolidinone (AMOZ), 3-amino-2-oxazolidinone (AOZ), 1aminohydantoin (AHD), and semicarbazide (SEM)]. The insets indicate the corresponding blanks (Reprinted from Yu et al. [59], with permission from Elsevier).

Figure 4 Schematic representation of the analytical method within the analytical protocol and respective sequential steps (Adapted from Taverniers et al. [74], with permission from Elsevier). 
Table 1 Analytical techniques for determination of contaminants in aquaculture samples.

\begin{tabular}{|c|c|c|c|c|c|c|c|c|c|c|c|}
\hline \multirow{2}{*}{ Contaminant } & \multirow{2}{*}{ Matrix } & \multirow{2}{*}{$\begin{array}{c}\text { Count } \\
\text { ry }\end{array}$} & \multirow{2}{*}{$\begin{array}{c}\text { Extraction } \\
\text { method }\end{array}$} & \multirow{2}{*}{$\begin{array}{l}\text { Clean-up } \\
\text { method }\end{array}$} & \multirow{2}{*}{$\begin{array}{l}\text { Instrumen } \\
\text { tal analysis }\end{array}$} & \multicolumn{5}{|c|}{ Analytical parameters } & \multirow{2}{*}{$\begin{array}{c}\text { Referen } \\
\text { ce }\end{array}$} \\
\hline & & & & & & $\begin{array}{c}\text { Analytical } \\
\text { range }\end{array}$ & $\mathbf{R}^{2}$ & Recovery (\%) & LOQ & LOD & \\
\hline $\mathrm{PCB}^{\mathrm{a}}$ & $\begin{array}{l}\text { Fish muscle } \\
\text { from sea bass } \\
\text { (Dicentrarchu } \\
s \quad \text { labrax), } \\
\text { gilthead sea } \\
\text { bream (Sparus } \\
\text { aurata), and } \\
\text { mussel } \\
\text { (Mitylus } \\
\text { galloprovincia } \\
\text { lis) }\end{array}$ & Italy & $\begin{array}{l}\text { Shaking } \\
\text { (PET:Ace, } \\
1: 1, \mathrm{v} / \mathrm{v})\end{array}$ & $\begin{array}{l}\text { Column } \\
\text { adsorption- } \\
\text { chromatogra } \\
\text { phy (Florisil; } \\
\text { elution: Hex) }\end{array}$ & GC-ECD & NI & NI & $70 \pm 7$ & NI & $\begin{array}{l}0.2(\mathrm{PCB} 180)- \\
0.66(\mathrm{PCB} 52) \mathrm{ng} \\
\mathrm{g}^{-1}\end{array}$ & [41] \\
\hline $\mathrm{PCB}^{\mathrm{a}, \mathrm{b}}$ & $\begin{array}{l}\text { Fish muscle } \\
\text { from rainbow } \\
\text { trout } \\
\text { (Oncorhynchu } \\
\text { s mykiss) }\end{array}$ & Italy & $\begin{array}{l}\text { ASE } \\
\text { (Hex:Ace, } \\
1: 1)\end{array}$ & $\begin{array}{l}\text { SPE } \\
\text { (Extrelut; } \\
\text { elution: Hex) }\end{array}$ & GC-ECD & $1-200 \mathrm{ng} \mathrm{mL}^{-1}$ & $>0.998$ & $\begin{array}{l}57 \pm 5 \quad(\text { PCB } \\
28)-136 \pm 11 \\
(\mathrm{PCB} 177)\end{array}$ & $2.5 \mathrm{ng} \mathrm{g}^{-1}$ & $\begin{array}{l}0.1 \quad(\mathrm{PCB} 105)- \\
1.4(\mathrm{PCB} 153) \mathrm{ng} \\
\mathrm{g}^{-1}\end{array}$ & [34] \\
\hline $\begin{array}{l}\text { Dioxin-like } \\
\text { PCB }^{\mathrm{c}} \text { and } \\
\text { dioxins } \\
\text { (PCDD and } \\
\text { PCBD) }\end{array}$ & $\begin{array}{l}\text { Fish fillets } \\
\text { from turbot } \\
(\text { Psetta } \\
\text { maxima })\end{array}$ & Spain & $\begin{array}{l}\text { Adsorption } \\
\text { chromatograp } \\
\text { hy (Hex:Ace, } \\
1: 1)\end{array}$ & $\begin{array}{l}\text { Multi-layer } \\
\text { silica gel } \\
\text { columns }\end{array}$ & $\begin{array}{l}\text { HRGC- } \\
\text { MS/MS }\end{array}$ & NI & NI & $50-85$ & NI & $\begin{array}{l}0.3-1.5 \mathrm{pg} \mathrm{g}^{-1} \text { for } \\
\text { dioxin-like PCB; } \\
0.05-1 \mathrm{pg} \mathrm{g}^{-1} \text { for } \\
\text { PCDD } \quad \text { and } \\
\text { PCBD (= } \mathrm{S} / \mathrm{N} \\
\text { ratio of 3) }\end{array}$ & [42] \\
\hline Non dioxin- & Fish muscles & Italy & ASE & Silica gel & GC-MS & NI & NI & NI & NI & NI & [8] \\
\hline
\end{tabular}




\begin{tabular}{|c|c|c|c|c|c|c|c|c|c|c|c|}
\hline like PCB & \multirow{2}{*}{$\begin{array}{l}\text { from rainbow } \\
\text { trout }(O . \\
\text { mykiss })\end{array}$} & & $\begin{array}{l}\text { (Hex:Ace, } \\
70: 30, v / v)\end{array}$ & columns & & & & & & & \\
\hline $\begin{array}{l}\text { Dioxin-like } \\
\mathrm{PCB}^{\mathrm{c}} \text { and } \\
\text { dioxins } \\
\text { (PCDD and } \\
\mathrm{PCBD})\end{array}$ & & & ASE (Tol) & $\begin{array}{l}\text { Multi- } \\
\text { column } \\
\text { chromatogra } \\
\text { phy with } \\
\text { silica gel, } \\
\text { and multi- } \\
\text { layer silica, } \\
\text { basic } \\
\text { alumina and } \\
\text { carbon }\end{array}$ & GC-HRMS & NI & NI & $75-120$ & $0.1 \mathrm{pg} \mathrm{g}^{-1}$ & NI & \\
\hline $\begin{array}{l}\mathrm{PCB}^{\mathrm{a}}, \mathrm{PBB}, \\
\mathrm{OCP} \quad(\mathrm{DDT} \\
\text { and } \mathrm{HCH}), \\
\text { and } \mathrm{PBDE}\end{array}$ & $\begin{array}{l}\text { Shellfish } \\
\text { (clam, mussel, } \\
\text { and cockle) }\end{array}$ & Spain & $\begin{array}{l}\text { SFE } \\
\text { (supercritical } \\
\mathrm{CO}_{2} \text { ) }\end{array}$ & $\begin{array}{l}\text { Aluminium } \\
\text { oxide } \\
\text { activated } \\
\text { basic and } \\
\text { acidic silica } \\
\text { gel }\end{array}$ & $\begin{array}{l}\text { GC- } \\
\text { MS/MS }\end{array}$ & $\begin{array}{l}10-400 \mathrm{ng} \mathrm{mL}^{-} \\
1\end{array}$ & $<0.994$ & $\begin{array}{l}76 \quad \text { (PCB-10 } \\
\text { and PBDE- } \\
99)-128 \\
(\text { PBDE-100) }\end{array}$ & $\begin{array}{l}0.05 \quad \text { (PCB- } \\
10)-2.33 \\
(\mathrm{PBDE}-47) \\
\mathrm{ng} \mathrm{g}^{-1}(=\mathrm{S} / \mathrm{N} \\
\text { ratio of } 10)\end{array}$ & $\begin{array}{l}0.01 \quad \text { (PCB-10)- } \\
0.70 \quad(\text { PBDE-47) } \\
n g \mathrm{~g}^{-1} \quad(=\mathrm{S} / \mathrm{N} \\
\text { ratio of 3) }\end{array}$ & [29] \\
\hline $\begin{array}{l}\mathrm{PCB}^{\mathrm{a}} \text { and } \\
\mathrm{OCP} \quad \text { (DDT, } \\
\mathrm{HCB} \text {, } \\
\text { heptachlor, } \\
\text { heptachlor } \\
\text { epoxide, } \\
\text { lindane, } \\
\text { methoxychlor, } \\
\text { and } \\
\text { endosulfan) }\end{array}$ & $\begin{array}{l}\text { Fish white and } \\
\text { red muscle } \\
\text { and liver from } \\
\text { gilthead sea } \\
\text { bream ( } \text {. } \\
\text { aurata) }\end{array}$ & Spain & $\begin{array}{l}\text { Refluxing } \\
\text { (Hex) }\end{array}$ & $\begin{array}{l}\text { HPLC } \\
\text { (mobile } \\
\text { phase: Hex } \\
\text { and EtOAc, } \\
1 \mathrm{~mL} \mathrm{~min}^{-1} \text { ) }\end{array}$ & $\begin{array}{l}\text { GC- } \\
\text { MS/MS }\end{array}$ & NI & NI & NI & $\begin{array}{l}0.3 \mathrm{ng} \mathrm{g}^{-1}(=9 \\
\text { times the } \\
\text { background } \\
\text { noise = } 3 \\
\text { times the } \\
\text { LOD) }\end{array}$ & $0.1 \mathrm{ng} \mathrm{g}^{-1}$ & [43] \\
\hline $\mathrm{PCB}^{\mathrm{a}, \mathrm{d}} \quad$ and & Fish muscles & Portug & Soxhlet & Solid-liquid & GC-EDC & NI & $\mathrm{NI}$ & $>80$ & $\mathrm{NI}$ & NI & [21] \\
\hline
\end{tabular}




\begin{tabular}{|c|c|c|c|c|c|c|c|c|c|c|c|}
\hline $\begin{array}{l}\text { OCP } \quad \text { (DDT, } \\
\mathrm{HCB}, \quad \text { and } \\
\text { lindane) }\end{array}$ & $\begin{array}{l}\text { from sea bass } \\
\text { (Dicentrarchu } \\
\text { s labrax) }\end{array}$ & $\begin{array}{l}\text { al and } \\
\text { Spain }\end{array}$ & $\begin{array}{l}\text { (Hex:DCM, } \\
4: 1)\end{array}$ & $\begin{array}{l}\text { adsorption } \\
\text { chromatogra } \\
\text { phy (elution: } \\
\mathrm{Hex}: \mathrm{DCM} \text {, } \\
\text { 1:2) with } \\
\text { previous } \\
\text { shaking with } \\
\mathrm{H}_{2} \mathrm{SO}_{4}\end{array}$ & & & & & & & \\
\hline $\begin{array}{l}\mathrm{PCB}^{\mathrm{a}, \mathrm{e}} \text { and } \\
\text { DDT }\end{array}$ & $\begin{array}{l}\text { Fish liver and } \\
\text { muscles from } \\
\text { sea bass ( } D . \\
\text { labrax) }\end{array}$ & $\begin{array}{l}\text { Portug } \\
\text { al }\end{array}$ & $\begin{array}{l}\text { Soxhlet } \\
\text { (Hex) }\end{array}$ & $\begin{array}{l}\text { SPE } \\
\text { (Florisil) }\end{array}$ & GC-ECD & NI & NI & NI & NI & $\begin{array}{l}0.01-0.04 \mathrm{ng} \mathrm{g}^{-1} \\
(=3 \sigma)\end{array}$ & [31] \\
\hline $\begin{array}{l}\text { OCP (DDT) } \\
\text { and PBDE }\end{array}$ & $\begin{array}{l}\text { Fish (crimson } \\
\text { sanpper } \\
\text { Lutjanus } \\
\text { malabaricus } \\
\text { and snubnose } \\
\text { pompano } \\
\text { Trachinotous } \\
\text { blochii) }\end{array}$ & China & $\begin{array}{l}\text { Soxhlet } \\
\text { (Ace:Hex, } \\
1: 1, \mathrm{v} / \mathrm{v})\end{array}$ & $\begin{array}{l}\text { Silica/alumin } \\
\text { a column }\end{array}$ & GC-MS & NI & NI & NI & NI & NI & [9] \\
\hline $\begin{array}{ll}\text { PCB, } & \text { OCP } \\
\text { (DDT), } & \text { and } \\
\text { PBDE } & \end{array}$ & $\begin{array}{l}\text { Fish (crimson } \\
\text { sanpper } L . \\
\text { malabaricus } \\
\text { and snubnose } \\
\text { pompano } T \text {. } \\
\text { blochii) }\end{array}$ & China & $\begin{array}{l}\text { Soxhlet } \\
\text { (Ace:Hex, } \\
1: 1, \mathrm{v} / \mathrm{v})\end{array}$ & $\begin{array}{l}\text { Gel } \\
\text { permeation } \\
\text { column and } \\
\text { silica/alumin } \\
\text { a column by } \\
\text { sequence }\end{array}$ & GC-MS & NI & NI & NI & NI & NI & [32] \\
\hline $\begin{array}{l}\text { Hydroxylated } \\
\text { PAH } \\
\text { naphtol, }\end{array}$ & $\begin{array}{l}\text { Fish bile from } \\
\text { sea bass ( } D . \\
\text { labrax) }\end{array}$ & $\begin{array}{l}\text { Portug } \\
\text { al and } \\
\text { Spain }\end{array}$ & EtOAc & $\begin{array}{l}\text { Solid-liquid } \\
\text { adsorption } \\
\text { chromatogra }\end{array}$ & GC-MS & NI & NI & NI & NI & NI & [21] \\
\hline
\end{tabular}




\begin{tabular}{|c|c|c|c|c|c|c|c|c|c|c|c|}
\hline $\begin{array}{l}\text { fluorenol, 9- } \\
\text { phenanthrol, } \\
\text { and 1- } \\
\text { pyrenol) and } \\
\text { alkylphenols } \\
\text { (4- } \\
\text { nonylphenol } \\
\text { and 4-tert- } \\
\text { octylphenol) }\end{array}$ & & & & $\begin{array}{l}\text { phy (elution: } \\
\text { Hex:DCM, } \\
\text { 1:2) with } \\
\text { previous } \\
\text { shaking with } \\
\mathrm{H}_{2} \mathrm{SO}_{4}\end{array}$ & & & & & & & \\
\hline $\mathrm{PAH}^{\mathrm{f}}$ & $\begin{array}{l}\text { Fish fillet } \\
\text { from gilthead } \\
\text { sea bream ( } S \text {. } \\
\text { aurata) }\end{array}$ & Spain & $\begin{array}{l}\text { Hex with } \\
\text { previous } \\
\text { saponificatio } \\
\mathrm{n} \\
(\mathrm{KOH} / \mathrm{MeOH} \\
1 \mathrm{M})\end{array}$ & $\begin{array}{l}\text { SPE } \\
\text { (Florisil; } \\
\text { elution: } \\
\text { DCM:Hex, } \\
\text { 20:80) }\end{array}$ & $\begin{array}{l}\text { GC- } \\
(\mathrm{QqQ}) \mathrm{MS} / \\
\mathrm{MS}\end{array}$ & $\begin{array}{l}0.2-200 \quad \mathrm{ng} \\
\mathrm{mL}^{-1}\end{array}$ & $<0.995$ & $80-110$ & NI & $\begin{array}{l}0.02 \\
\text { (acenaphthene } \\
\text { and } \\
\text { benzo[a]anthrace } \\
\text { ne)-0.1 (fluorene, } \\
\text { phenanthrene, } \\
\text { fluoranthene, and } \\
\text { pyrene) } \mu \mathrm{g} \mathrm{kg}^{-1} \\
(=3.3 \sigma / \mathrm{slope})\end{array}$ & [27] \\
\hline $\begin{array}{l}\text { PAH } \\
\text { (phenanthrene } \\
\text {, naphthalene, } \\
\text { benzo[a]pyren } \\
\text { e, and pyrene- } \\
\text { derived } \\
\text { metabolites) }\end{array}$ & $\begin{array}{l}\text { Fish bile from } \\
\text { sea bass }(D . \\
\text { labrax })\end{array}$ & $\begin{array}{l}\text { Portug } \\
\text { al }\end{array}$ & $\mathrm{EtOH}$ & - & Fluorimeter & NI & NI & NI & NI & NI & [31] \\
\hline $\begin{array}{l}\text { Antibiotics } \\
\text { (ciprofloxacin } \\
\text { danofloxacin, }\end{array}$ & $\begin{array}{l}\text { Fish muscle } \\
\text { from salmon, } \\
\text { shrimp, and } \\
\text { tilapia }\end{array}$ & Canada & $\begin{array}{l}\text { Acidic ACN } \\
\text { (with } \\
\text { perchloric } \\
\text { acid) }\end{array}$ & $\begin{array}{l}\text { SPE (C18 } \\
\text { cartridges; } \\
\text { elution: } \\
\text { ACN })\end{array}$ & $\begin{array}{l}\text { UHPLC- } \\
\text { MS/MS }\end{array}$ & $0.2-150 \mathrm{ng} \mathrm{g}^{-1}$ & NI & $\begin{array}{l}\text { 73(danofloxaci } \\
\text { n)-95 } \\
\text { (sarafloxacin) } \\
\text { for salmon }\end{array}$ & $\begin{array}{l}0.11 \\
\text { (enrofloxacin } \\
\text { )-0.55 } \mathrm{ng} \mathrm{g}^{-1} \\
\text { (ciprofloxacin }\end{array}$ & $\begin{array}{l}0.04 \\
\text { (enrofloxacin)- } \\
0.18 \quad \mathrm{ng} \mathrm{g}^{-1} \\
\text { (ciprofloxacin) }\end{array}$ & [44] \\
\hline
\end{tabular}




\begin{tabular}{|c|c|c|c|c|c|c|c|c|c|c|c|}
\hline $\begin{array}{l}\text { enrofloxacin, } \\
\text { and } \\
\text { sarafloxacin) }\end{array}$ & & & & & & & & $\begin{array}{l}\text { tissue, } \\
\text { 71(danofloxaci } \\
\text { n)-109 } \\
\text { (sarafloxacin) } \\
\text { for shrimp, and } \\
\text { 62(danofloxaci } \\
\text { n)-111 } \\
\text { (sarafloxacin) } \\
\text { for tilapia }\end{array}$ & $\begin{array}{l}\text { ) for salmon, } \\
0.4 \\
\text { (enrofloxacin } \\
\text { )-0.56 } \mathrm{ng} \mathrm{g}^{-1} \\
\text { (ciprofloxacin } \\
\text { ) for shrimp, } \\
0.06 \\
\text { (enrofloxacin } \\
\text { )-0.37 ng g }{ }^{-1} \\
\text { (ciprofloxacin } \\
\text { ) for tilapia }\end{array}$ & $\begin{array}{l}\text { for salmon, } 0.13 \\
\text { (enrofloxacin)- } \\
0.19 \mathrm{ng} \mathrm{g}^{-1} \\
\text { (ciprofloxacin) } \\
\text { for shrimp, } 0.02 \\
\text { (enrofloxacin)- } \\
0.12 \mathrm{ng} \mathrm{g}^{-1} \\
\text { (ciprofloxacin) } \\
\text { for tilapia (= S/N } \\
\text { ratio of 3) }\end{array}$ & \\
\hline $\begin{array}{l}\text { Antibiotics } \\
\text { (sulfonamides } \\
\text { trimethoprim, } \\
\text { tetracyclines, } \\
\text { macrolides, } \\
\text { quinolones, } \\
\text { penicillins, } \\
\text { and } \\
\text { chlorampheni } \\
\text { col) }\end{array}$ & $\begin{array}{l}\text { Fish muscles } \\
\text { from gilthead } \\
\text { sea bream ( } S \text {. } \\
\text { aurata) }\end{array}$ & $\begin{array}{l}\text { Portug } \\
\text { al }\end{array}$ & ACN:EDTA ${ }^{\mathrm{g}}$ & - & $\begin{array}{l}\text { UHPLC- } \\
\text { MS/MS }\end{array}$ & $\begin{array}{l}50-300^{\mathrm{h}} \mu \mathrm{g} \mathrm{kg}^{-} \\
1\end{array}$ & NI & $\begin{array}{l}15 \\
\text { (sulfanilamide) } \\
-108 \\
\text { (chlorampheni } \\
\text { col) }\end{array}$ & NI & NI & [45] \\
\hline $\begin{array}{l}\text { Antibiotics } \\
\text { (ciprofloxacin } \\
\text { danofloxacin, } \\
\text { enrofloxacin, } \\
\text { sarafloxacin, } \\
\text { oxolinic }\end{array}$ & $\begin{array}{l}\text { Fish muscle } \\
\text { from gilthead } \\
\text { sea bream ( } S \text {. } \\
\text { aurata) }\end{array}$ & Greece & $\begin{array}{l}\text { Sonication } \\
\text { (15 min.) and } \\
\text { centrifugatio } \\
\text { n }(10 \text { min., } \\
3500 \mathrm{rpm})\end{array}$ & $\begin{array}{l}\text { SPE (HLB } \\
\text { cartridges; } \\
\text { elution: } \\
\text { TFA:ACN) }\end{array}$ & $\begin{array}{l}\text { HPLC- } \\
\text { DAD }\end{array}$ & $\begin{array}{l}10-1000 \quad \mu \mathrm{g} \\
\mathrm{kg}^{-1}\end{array}$ & $\begin{array}{l}0.9971 \\
\text { (danofloxaci } \\
\text { n)- } 0.9999 \\
\text { (ciprofloxaci } \\
\text { n) }\end{array}$ & $94.9-100.2$ & $\begin{array}{l}5.1 \\
\text { (ciprofloxacin } \\
\text { )-28.5 } \\
\text { (danofloxacin } \\
\text { ) } \mu \mathrm{g} \quad \mathrm{kg}^{-1} \\
(=10 \sigma / \text { slope) }\end{array}$ & $\begin{array}{l}1.7 \\
\text { (ciprofloxacin)- } \\
9.5 \\
\text { (danofloxacin) } \\
\mu \mathrm{g} \quad \mathrm{kg}^{-1} \\
(=3.3 \sigma / \text { slope })\end{array}$ & [46] \\
\hline
\end{tabular}




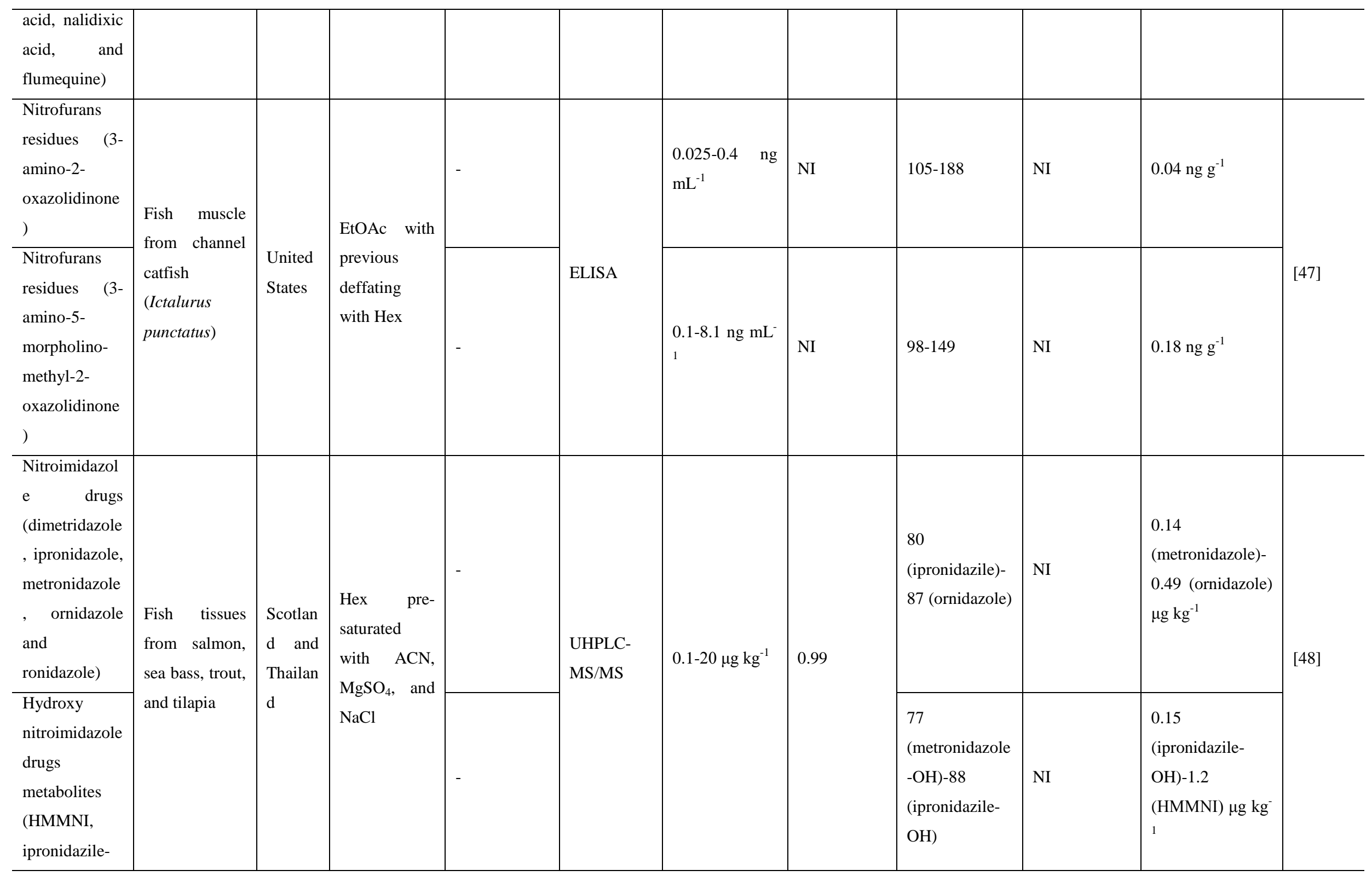




\begin{tabular}{|c|c|c|c|c|c|c|c|c|c|c|c|}
\hline $\begin{array}{l}\mathrm{OH} \text { and } \\
\text { metronidazole } \\
-\mathrm{OH})\end{array}$ & & & & & & & & & & & \\
\hline $\begin{array}{l}\text { Antibiotics } \\
\text { (flumequine, } \\
\text { oxolinic acid, } \\
\text { sarafloxacin, } \\
\text { danofloxacin, } \\
\text { enrofloxacin, } \\
\text { and } \\
\text { ciprofloxacin) }\end{array}$ & $\begin{array}{l}\text { Fish fillets } \\
\text { from tilapia } \\
\text { (Orechromis } \\
\text { niloticus) }\end{array}$ & Brazil & $\begin{array}{l}10 \% \\
\text { trichloroaceti } \\
\text { c acid:MeOH } \\
(8: 2, \mathrm{v} / \mathrm{v})\end{array}$ & $\begin{array}{l}\text { SPE (HBL } \\
\text { cartridges; } \\
\text { elution: } \\
\text { ACN: } \mathrm{NH}_{4} \mathrm{O} \\
\mathrm{H}, 8: 2, \mathrm{v} / \mathrm{v})\end{array}$ & HPLC-FLD & $\begin{array}{l}50-300 \mathrm{ng} \mathrm{g}^{-1} \\
\text { (oxolinic acid, } \\
\text { enrofloxacin, } \\
\text { and } \\
\text { ciprofloxacin); } \\
25-150 \mathrm{ng} \mathrm{g}^{-1} \\
\text { (danofloxacin) } \\
; \\
15-90 \mathrm{ng} \mathrm{g}^{-1} \\
\text { (sarafloxacin); } \\
\text { 100-600 ng g } \\
\text { (flumequine) }\end{array}$ & $>0.99$ & $73-110$ & $\begin{array}{l}5 \\
\text { (danofloxacin } \\
\text { )-27 } \\
\text { (sarafloxacin) } \\
\operatorname{ng~g}^{-1}(=\mathrm{S} / \mathrm{N} \\
\text { ratio of } 3)\end{array}$ & $\begin{array}{l}2 \text { (danofloxacin)- } \\
8 \text { (sarafloxacin) } \\
\mathrm{ng} \mathrm{g}^{-1}(=\mathrm{S} / \mathrm{N} \\
\text { ratio of } 3)\end{array}$ & [49] \\
\hline $\begin{array}{l}\text { Antibiotics } \\
\text { (sulfonamides } \\
\text { and } \\
\text { tetracyclines) }\end{array}$ & $\begin{array}{l}\text { Fish (sea } \\
\text { bream and sea } \\
\text { bass) }\end{array}$ & Greece & $\begin{array}{l}\mathrm{MeOH}: \mathrm{ACN} \\
(50: 50, \mathrm{v} / \mathrm{v}) \\
\text { with } 0.05 \% \\
(\mathrm{v} / \mathrm{v}) \quad \text { of } \\
\text { formic acid }\end{array}$ & - & $\begin{array}{l}\text { UHPLC- } \\
\text { MS/MS }\end{array}$ & $20-150 \mu \mathrm{g} \mathrm{kg}^{-1}$ & $>0.98$ & NI & $\begin{array}{l}17.1 \\
\text { (sulfamerazin } \\
\text { e)-72.7 } \\
\text { (sulfaguanidi } \\
\text { ne) } \mu \mathrm{g} \mathrm{kg}^{-1} \text { (= } \\
10 \sigma)\end{array}$ & $\begin{array}{l}5.65 \\
\text { (sulfamerazine)- } \\
25 \\
\text { (oxytetracycline) } \\
\mu \mathrm{g} \mathrm{kg}^{-1}(=3.3 \sigma)\end{array}$ & {$[50]$} \\
\hline $\begin{array}{l}\text { Antibiotics } \\
\text { (sulfonamides } \\
\text {, tetracyclines, } \\
\text { and } \\
\text { quinolones) }\end{array}$ & Shrimp & USA & $\begin{array}{l}\text { MeOH:CAN } \\
(1: 3)\end{array}$ & $\begin{array}{l}\text { Online SPE } \\
\text { (PolymerX } \\
\text { RP-1 guard } \\
\text { cartridge) }\end{array}$ & $\begin{array}{l}\text { HPLC- } \\
\text { MS/MS }\end{array}$ & NI & $>0.99$ & $77-115$ & NI & NI & [51] \\
\hline Antibiotics & $\begin{array}{l}\text { Fish (bream, } \\
\text { roach, pike, } \\
\text { zander, and }\end{array}$ & Poland & $\begin{array}{l}\text { Phosphoric } \\
\text { acid:HFBA } \\
\text { and ACN }\end{array}$ & $\begin{array}{l}\text { SPE (Strata } \\
\text { X-CW } \\
\text { cartridges; }\end{array}$ & LC-MS/MS & NI & $>0.99$ & $96-111$ & NI & NI & [52] \\
\hline
\end{tabular}




\begin{tabular}{|c|c|c|c|c|c|c|c|c|c|c|c|}
\hline & catfish) & & & $\begin{array}{l}\text { elution: } \\
\text { formic acid } \\
\text { in } \mathrm{MeOH} \text { ) }\end{array}$ & & & & & & & \\
\hline Steroids & $\begin{array}{l}\text { Fish (Lutjanus } \\
\text { russelli, } \\
\text { Lutjanus } \\
\text { erythopterus, } \\
\text { and } \\
\text { Trachinotus } \\
\text { ovatus), } \\
\text { mollusks } \\
\text { (Atrina } \\
\text { pectinate } \\
\text { Linnaeu, } \\
\text { Meretrix } \\
\text { lusoria, } \\
\text { Trisidos } \\
\text { kiyoni, and } \\
\text { Crassostrea } \\
\text { rivularis } \\
\text { Gould), crabs } \\
\text { (Calappa } \\
\text { philargius), } \\
\text { and } \\
\text { shrimps } \\
\text { (Fenneropena } \\
\text { eus } \\
\text { penicillatus) }\end{array}$ & China & $\begin{array}{l}\text { Ultrasonicati } \\
\text { on } \\
\left(\mathrm{MeOH} / \mathrm{H}_{2} \mathrm{O}-\right. \\
0.1 \mathrm{M} \text { acetic } \\
\text { acid, 50:50, } \\
\mathrm{v} / \mathrm{v})\end{array}$ & $\begin{array}{l}\text { SPE } \\
\text { (SAX/PSA } \\
\text { cartridges) }\end{array}$ & $\begin{array}{l}\text { RRLC- } \\
\text { MS/MS }\end{array}$ & $1-1000 \mu \mathrm{g} \mathrm{L}^{-1}$ & $>0.99$ & NI & $\begin{array}{l}0.06 \quad(4- \\
\text { androstene- } \\
3,17 \text {-dione } \\
\text { and } \\
\text { progesterone) } \\
-7.84 \\
\text { (cortisol) } \mathrm{ng} \\
\mathrm{g}^{-1} \quad(=\mathrm{S} / \mathrm{N} \\
\text { ratio of } 10)\end{array}$ & $\begin{array}{l}0.02 \\
\text { androstene-3,17- } \\
\text { dione, ethynyl } \\
\text { testoterone, and } \\
\text { progesterone)- } \\
2.35 \text { (cortisol) ng } \\
\mathrm{g}^{-1}(=\mathrm{S} / \mathrm{N} \text { ratio } \\
\text { of 3) }\end{array}$ & [40] \\
\hline $\mathrm{Cu}, \mathrm{Zn}$, and & Fish liver and & Portug & Digestion & - & Atomic & NI & NI & NI & NI & NI & [21] \\
\hline
\end{tabular}




\begin{tabular}{|c|c|c|c|c|c|c|c|c|c|c|c|}
\hline $\mathrm{Cd}$ & $\begin{array}{l}\text { muscles from } \\
\text { sea bass }(D . \\
\text { labrax) }\end{array}$ & $\begin{array}{l}\text { al and } \\
\text { Spain }\end{array}$ & $\left(\mathrm{HNO}_{3}\right)$ & & $\begin{array}{l}\text { absorption } \\
\text { spectrometr } \\
\text { y }\end{array}$ & & & & & & \\
\hline $\begin{array}{l}\mathrm{Cu}, \mathrm{As}, \mathrm{Cd} \text {, } \\
\text { and } \mathrm{Pb}\end{array}$ & $\begin{array}{l}\text { Fish liver and } \\
\text { muscles from } \\
\text { sea bass ( } D . \\
\text { labrax) }\end{array}$ & $\begin{array}{l}\text { Portug } \\
\text { al }\end{array}$ & $\begin{array}{l}\text { Digestion } \\
\left(\mathrm{HNO}_{3}: \mathrm{H}_{2} \mathrm{O}_{2},\right. \\
1: 1, \mathrm{v} / \mathrm{v})\end{array}$ & - & ICP-MS & $1-100 \mu \mathrm{g} \mathrm{L}^{-1}$ & NI & NI & NI & NI & [31] \\
\hline $\mathrm{Cd}$ and $\mathrm{Pb}$ & $\begin{array}{l}\text { Fish liver, } \\
\text { kidney, gills, } \\
\text { gut, and } \\
\text { muscles from } \\
\text { sea bream ( } S . \\
\text { aurata) }\end{array}$ & Italy & $\begin{array}{l}\text { Digestion } \\
\left(\mathrm{HNO}_{3}\right)\end{array}$ & - & $\begin{array}{l}\text { Atomic } \\
\text { absorption } \\
\text { spectrometr } \\
\text { y }\end{array}$ & NI & NI & NI & NI & $\begin{array}{l}5-15 \mathrm{ng} \mathrm{g}^{-1} \text { for } \\
\mathrm{Pb} \text { and } 1-5 \mathrm{ng} \mathrm{g}^{-1} \\
\text { for } \mathrm{Cd}(=3 \sigma)\end{array}$ & [6] \\
\hline $\begin{array}{l}\mathrm{Cd}, \mathrm{Cr}, \mathrm{Cu}, \\
\mathrm{Fe}, \mathrm{Mn}, \text { and } \\
\mathrm{Zn}\end{array}$ & $\begin{array}{l}\text { Fish muscle, } \\
\text { shell, and liver } \\
\text { from white } \\
\text { shrimp } \\
\text { (Litopenaeus } \\
\text { vannamei) }\end{array}$ & China & $\begin{array}{l}\text { Digestion } \\
\left(\mathrm{HNO}_{3}\right)\end{array}$ & - & ICP-MS & NI & NI & $\begin{array}{l}92 \quad(\mathrm{Mn})-101 \\
(\mathrm{Cd})\end{array}$ & NI & NI & [53] \\
\hline $\begin{array}{l}\mathrm{Cd}, \mathrm{As}, \mathrm{Cd}, \\
\mathrm{Pb}, \mathrm{Cu}, \mathrm{Ba}, \\
\mathrm{Co}, \text { and } \mathrm{Mn}\end{array}$ & $\begin{array}{l}\text { Fish (big-head } \\
\text { carps, grass } \\
\text { carps, carps, } \\
\text { and tilapias) }\end{array}$ & China & $\begin{array}{l}\text { Microwave } \\
\text { digestion } \\
\left(\mathrm{H}_{2} \mathrm{O}_{2}\right)\end{array}$ & - & ICP-MS & NI & NI & NI & NI & NI & [54] \\
\hline $\mathrm{Pb}$ and $\mathrm{Cd}$ & $\begin{array}{l}\text { Fish muscles } \\
\text { from rainbow } \\
\text { trout }(O . \\
\text { mykiss })\end{array}$ & Italy & $\begin{array}{l}\text { Digestion } \\
\left(\mathrm{HNO}_{3}\right)\end{array}$ & - & $\begin{array}{l}\text { Atomic } \\
\text { absorption } \\
\text { spectrometr } \\
\text { y }\end{array}$ & $\begin{array}{l}0-10(\mathrm{~Pb}) \text { and } \\
0-0.6(\mathrm{Cd}) \mathrm{ng} \\
\mathrm{mL}^{-1}\end{array}$ & NI & $\begin{array}{l}97 \pm 6(\mathrm{~Pb}) \text { and } \\
83 \pm 7(\mathrm{Cd})\end{array}$ & $\begin{array}{l}0.06(\mathrm{~Pb}) \text { and } \\
0.0009 \quad(\mathrm{Cd}) \\
\mu \mathrm{g} \mathrm{g}^{-1}\end{array}$ & $\begin{array}{lll}0.02 & (\mathrm{~Pb}) & \text { and } \\
0.0003 & (\mathrm{Cd}) & \mu \mathrm{g} \\
\mathrm{g}^{-1} & & \end{array}$ & [8] \\
\hline $\mathrm{PCB}^{\mathrm{i}}$ & Sediments & Scotlan & ASE & Alumina and & GC-ECD & $0.002-0.2 \mu \mathrm{g} \mathrm{g}^{-}$ & NI & NI & $0.02-0.10 \mu \mathrm{g}$ & NI & [55] \\
\hline
\end{tabular}




\begin{tabular}{|c|c|c|c|c|c|c|c|c|c|c|c|}
\hline & & $\mathrm{d}$ & & $\begin{array}{l}\text { silica } \\
\text { columns }\end{array}$ & & & & & $\mathrm{kg}^{-1}$ & & \\
\hline $\begin{array}{l}\mathrm{OCP} \quad(\mathrm{HCH} \\
\text { and DDT })\end{array}$ & & China & $\begin{array}{l}\text { Soxhlet } \\
\text { (Ace:DCM:H } \\
\text { ex, 1:1:1, } \\
\text { v/v/v) }\end{array}$ & $\begin{array}{l}\text { Multi-layer } \\
\text { silica gel } \\
\text { column and } \\
\text { SPE } \\
\text { (Florisil) }\end{array}$ & GC-MS & NI & NI & $93.7 \pm 13.6$ & NI & $\begin{array}{l}0.02 \mathrm{ng} \mathrm{g}^{-1}(= \\
\mathrm{S} / \mathrm{N} \text { ratio of } 3)\end{array}$ & [56] \\
\hline $\mathrm{PAH}^{\mathrm{e}}$ & & China & $\begin{array}{l}\text { Soxhlet } \\
\text { (Ace:DCM:H } \\
\text { ex, 1:1:1, } \\
\text { v/v/v) }\end{array}$ & $\begin{array}{l}\text { SPE } \\
\text { (Florisil) }\end{array}$ & GC-MS & $0-200 \mathrm{ng} \mathrm{g}^{-1}$ & NI & NI & NI & $\begin{array}{l}0.03-0.10 \mathrm{ng}^{-1} \\
(=\mathrm{S} / \mathrm{N} \text { ratio of } 3)\end{array}$ & [57] \\
\hline $\mathrm{PAH}^{\mathrm{e}}$ & & Italia & $\begin{array}{l}\text { Soxhlet } \\
\text { (DCM) }\end{array}$ & $\begin{array}{l}\text { Silica gel } \\
\text { column } \\
\text { (elution: } \\
\text { Hex:DCM, } \\
1: 1, \mathrm{v} / \mathrm{v} \text { ) }\end{array}$ & HPLC & NI & $>0.99$ & NI & NI & $\begin{array}{l}0.01-0.5 \mathrm{ng} \mathrm{g}^{-1}(= \\
3 \sigma)\end{array}$ & [58] \\
\hline $\mathrm{PAH}^{\mathrm{e}}$ & & $\begin{array}{l}\text { Malays } \\
\text { ia }\end{array}$ & $\begin{array}{l}\text { Soxhlet } \\
\text { (DCM) }\end{array}$ & $\begin{array}{l}\text { Silica gel } \\
\text { column } \\
\text { chromatogra } \\
\text { phy (elution: } \\
\text { Hex:DCM, } \\
3: 1, \mathrm{v} / \mathrm{v} \text { ) }\end{array}$ & GC-MS & $0.05-1.0 \mathrm{ng} \mathrm{g}^{-1}$ & $>0.993$ & $\begin{array}{l}45 \\
\text { (naphthalene)- } \\
121 \\
\text { (benzo(e)pyren } \\
\text { e) }\end{array}$ & NI & $\begin{array}{l}0.06 \\
\text { (acenaphthene)- } \\
7.0 \text { (retene) } \mathrm{ng} \mathrm{g}^{-} \\
1\end{array}$ & [28] \\
\hline PBDE & & $\begin{array}{l}\text { Scotlan } \\
\text { d }\end{array}$ & ASE & $\begin{array}{l}\text { Alumina and } \\
\text { silica } \\
\text { columns }\end{array}$ & GC-EC-MS & NI & NI & NI & $\begin{array}{l}0.03-0.10 \mu \mathrm{g} \\
\mathrm{kg}^{-1}\end{array}$ & $0.07 \mu \mathrm{g} \mathrm{kg}^{-1}$ & [55] \\
\hline $\begin{array}{l}\text { Nitrofurans } \\
\text { (FTD, FZD, } \\
\text { NFT, and }\end{array}$ & $\begin{array}{l}\text { Sediments } \\
\text { slurries }\end{array}$ & Taiwan & DMF & - & $\begin{array}{l}\text { HPLC- } \\
\text { DAD }\end{array}$ & $0.2-5 \mathrm{mg} \mathrm{L}^{-1}$ & $>0.99$ & $\begin{array}{l}79.0 \quad(\text { FZD)- } \\
82.7 \text { (NFZ) }\end{array}$ & $\begin{array}{l}0.3(\mathrm{NFZ})-1.0 \\
(\mathrm{FTD}) \mathrm{mg} \mathrm{L}^{-1} \\
(=\mathrm{S} / \mathrm{N} \text { ratio }\end{array}$ & $\begin{array}{l}0.2 \text { (NFZ)-0.6 } \\
\left(\text { FTD) } \mathrm{mg} \mathrm{L}^{-1}(=\right. \\
\mathrm{S} / \mathrm{N} \text { ratio of } 3)\end{array}$ & [59] \\
\hline
\end{tabular}




\begin{tabular}{|c|c|c|c|c|c|c|c|c|c|c|c|}
\hline NFZ) & & & & & & & & & of 5) & & \\
\hline $\begin{array}{l}\text { Nitrofurans } \\
\text { metabolites } \\
\text { (AMOZ, } \\
\text { AOZ, AHD, } \\
\text { SEM) }\end{array}$ & & & EtOAc & - & LC-MS/MS & $1-40 \mu \mathrm{g} \mathrm{L}^{-1}$ & NI & $\begin{array}{l}90.4 \quad(\mathrm{SEM})- \\
94.9 \text { (AMOZ) }\end{array}$ & $\begin{array}{l}0.3 \quad(\mathrm{AMOZ} \\
\text { and } \mathrm{AOZ})-1.0 \\
(\mathrm{SEM}) \mathrm{mg} \mathrm{L}^{-1} \\
(=\mathrm{S} / \mathrm{N} \text { ratio } \\
\text { of } 5)\end{array}$ & $\begin{array}{l}0.2(\mathrm{AMOZ})-0.6 \\
(\mathrm{SEM}) \mu \mathrm{g} \mathrm{L}^{-1}(= \\
\mathrm{S} / \mathrm{N} \text { ratio of } 3)\end{array}$ & \\
\hline Steroids & Sediments & China & EtOAc & $\begin{array}{l}\text { Silica gel } \\
\text { columns }\end{array}$ & $\begin{array}{l}\text { RRLC- } \\
\text { MS/MS }\end{array}$ & NI & NI & NI & 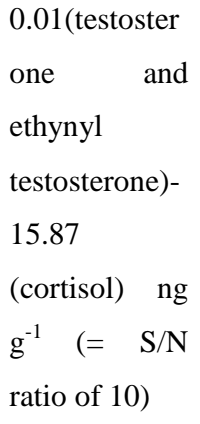 & $\begin{array}{l}0.004 \\
\text { (testosterone)- } \\
4.76 \text { (cortisol) ng } \\
\mathrm{g}^{-1}(=\mathrm{S} / \mathrm{N} \text { ratio } \\
\text { of } 3)\end{array}$ & [40] \\
\hline $\mathrm{Cu}$ and $\mathrm{Zn}$ & & $\begin{array}{l}\text { Scotlan } \\
\text { d }\end{array}$ & $\begin{array}{l}\text { Digestion } \\
\left(\mathrm{HNO}_{3}\right)\end{array}$ & $\begin{array}{l}\text { Alumina and } \\
\text { silica } \\
\text { columns }\end{array}$ & ICP-MS & $5-400 \mu \mathrm{g} \mathrm{L}^{-1}$ & NI & NI & NI & $\mathrm{NI}$ & [55] \\
\hline $\mathrm{PCB}^{\mathrm{a}}$ & \multirow{3}{*}{ Water } & Italy & - & - & GC-ECD & NI & NI & $76 \pm 4$ & NI & $\begin{array}{l}0.08 \text { (PCB 138, } \\
153 \text {, and 180)- } \\
0.10 \quad(\mathrm{PCB} 28 \\
\text { and } 52) \mathrm{ng} \mathrm{L}^{-1}\end{array}$ & [41] \\
\hline $\begin{array}{l}\text { Nitrofurans } \\
\text { (FTD, FZD, } \\
\text { NFT, } \\
\text { NFZ) }\end{array}$ & & \multirow[t]{2}{*}{ Taiwan } & - & - & $\begin{array}{l}\text { HPLC- } \\
\text { DAD }\end{array}$ & NI & NI & $100.1-102.1$ & $\begin{array}{l}0.08 \quad \text { (NFZ)- } \\
0.2 \text { (FTD) mg } \\
\mathrm{L}^{-1}\end{array}$ & $\begin{array}{l}0.05 \quad \text { (NFZ)-0.1 } \\
\text { (FTD) } \mathrm{mg} \mathrm{L}^{-1}\end{array}$ & \multirow[t]{2}{*}[59]{} \\
\hline $\begin{array}{l}\text { Nitrofurans } \\
\text { metabolites } \\
\text { (AMOZ, }\end{array}$ & & & - & - & LC-MS/MS & NI & NI & $92.2-102.3$ & $\begin{array}{l}0.3 \text { (AMOZ)- } \\
0.7 \quad \text { (SEM) } \\
\mathrm{mg} \mathrm{L}^{-1}\end{array}$ & $\begin{array}{l}0.2 \text { (AMOZ)-0.4 } \\
(\mathrm{SEM}) \mathrm{mg} \mathrm{L}^{-1}\end{array}$ & \\
\hline
\end{tabular}




\begin{tabular}{|c|c|c|c|c|c|c|c|c|c|c|}
\hline $\begin{array}{l}\text { AOZ, AHD, } \\
\text { and SEM) }\end{array}$ & & & & & & & & & & \\
\hline $\begin{array}{l}\text { Non dioxin- } \\
\text { like PCB, } \\
\text { dioxin-like } \\
\mathrm{PCB}^{\mathrm{c}} \text {, and } \\
\text { dioxins } \\
(\mathrm{PCDD} \quad \text { and } \\
\mathrm{PCBD})\end{array}$ & Italy & $\begin{array}{l}\text { SPE (glass } \\
\text { fiber; elution: } \\
\text { Tol:MeOH) }\end{array}$ & $\begin{array}{l}\text { Gel } \\
\text { permeation, } \\
\text { alumina, } \\
\text { silica gel, } \\
\text { Florisil, and } \\
\text { activated } \\
\text { carbon } \\
\text { chromatogra } \\
\text { phy }\end{array}$ & $\begin{array}{l}\text { HRGC- } \\
\text { HRMS }\end{array}$ & NI & NI & NI & NI & NI & [8] \\
\hline Steroids & China & $\begin{array}{l}\text { SPE (HLB } \\
\text { cartridges; } \\
\text { elution: } \\
\mathrm{MeOH})\end{array}$ & - & $\begin{array}{l}\text { RRLC- } \\
\text { MS/MS }\end{array}$ & NI & NI & NI & $\begin{array}{l}0.05 \\
\text { (stanozolol)- } \\
5.93 \text { (cortisol) } \\
\mathrm{ng} \mathrm{g}^{-1}(=\mathrm{S} / \mathrm{N} \\
\text { ratio of } 10)\end{array}$ & $\begin{array}{l}0.02 \\
\text { (stanozolol)-1.78 } \\
\text { (cortisol) ng } \mathrm{g}^{-1} \\
(=\mathrm{S} / \mathrm{N} \text { ratio of } 3 \text { ) }\end{array}$ & {$[40]$} \\
\hline $\begin{array}{l}\text { Antibiotics } \\
\text { (enrofloxacin, } \\
\text { ciprofloxacin, } \\
\text { norfloxacin, } \\
\text { levofloxacin, } \\
\text { danofloxacin, } \\
\text { and } \\
\text { sarafloxacin) }\end{array}$ & Spain & $\begin{array}{l}\text { Online SPE } \\
\left(\mathrm{H}_{2} \mathrm{O}: \mathrm{ACN},\right. \\
74: 26, \quad \mathrm{v} / \mathrm{v} \\
\text { with } \quad 0.5 \% \\
\text { TFA) }\end{array}$ & - & HPLC-FLD & 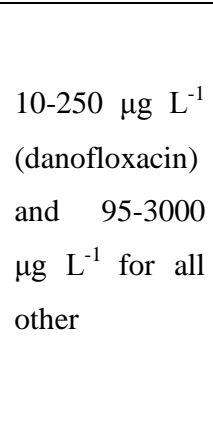 & NI & $91-102$ & NI & $\begin{array}{l}1 \text { (danofloxacin)- } \\
12 \text { (norfloxacin) } \\
\mathrm{ng} \mathrm{L}^{-1}(=3.3 . \sigma)\end{array}$ & {$[60]$} \\
\hline$(\mathrm{Pb}$ and $\mathrm{Cd}$ & Italy & - & - & ICP-AES & NI & NI & NI & NI & NI & {$[8]$} \\
\hline
\end{tabular}

${ }^{\mathrm{a}}$ Sum of PCB congeners 28, 52, 101, 118, 138, 153, and 180;

${ }^{\mathrm{b}}$ Sum of PCB congeners 95, 99, 105, 110, 146, 149, 151, 170, 177, 183, and 187;

${ }^{\mathrm{c}}$ Sum of PCB congeners 77, 81, 105, 114, 118, 123, 126, 156, 157, 167, 169, and 189;

${ }^{\mathrm{d}}$ Sum of PCB congeners 18, 31, 44, 149, 170, 194, and 209; 
${ }^{\mathrm{e}}$ Sum of PCB congeners 18, 44, 49, 105, 128, 149, 151, 170, 183, 187, and 194;

${ }_{\mathrm{f}}^{\mathrm{f}}$ Naphthalene, acenaphthylene, acenaphthene, fluorene, phenanthrene, anthracene, fluoranthene, pyrene, benzo[a]anthracene, chrysene, benzo[b]fluoranthene, benzo[k]fluoranthene, benzo[a]pyrene, indeno[1,2,3-cd]pyrene, dibenzo[a,h]anthracene, and benzo[g,h,i]perylene;

${ }^{g}$ Better extraction in comparison to the other 13 extraction proposed;

${ }^{\mathrm{h}}$ For the majority of antibiotics;

${ }^{\mathrm{i}}$ Sum of PCB congeners 35, 53, 112, 151, 198, and 209.

Ace: acetone; ACN; acetonitrile; AMOZ: 3-amino-5-morpholinomethyl-2-oxazolidinone; AHD: 1-aminohydantoin; ASE: accelerated solvent extraction; AOZ: 3-amino-2oxazolidinone; DCM: dichloromethane; DDT: dichlorodiphenyltrichloroethane; DMF: dimethylformamide; EDTA: ethylenediamine tetraacetic acid; ELISA: enzyme-linked immunosorbent assay; EtOAc: ethyl acetate; EtOH: ethanol; FTD: furaltadone; FZD: furazolidone; GC-ECD: gas chromatography with electron capture detection; GC-EC-MS: gas chromatography-electron capture mass spectroscopy; GC-HRMS: gas chromatography high-resolution mass spectrometry; GC-MS: gas chromatography coupled to mass spectrometry; GC-MS/MS: gas chromatography coupled to tandem mass spectrometry; GC-(QqQ)MS/MS: gas chromatography coupled to tandem mass spectrometry with a triple quadrupole analyzer; HCB: hexachlorobenzene; HCH: hexachlorocyclohexane; Hex: hexane; HFBA: heptafluorobutyric acid; HLB: hydrophilic lipophilic balanced; HMMNI: 1-methyl-5-nitro-1H-imidazole-2-methanol; HPLC: high performance liquid chromatography; HPLC-DAD: high performance liquid chromatography with diode array detector; HPLC-FLD: high performance liquid chromatography with fluorescence detection; HRGC-HRMS: high resolution gas chromatography coupled to high resolution mass spectrometry; HRGC-MS/MS: high-resolution gas chromatography coupled to tandem mass spectrometry; ICP-AES: inductively coupled plasma atomic emission spectrometry; ICP-MS: inductively coupled plasma mass spectrometry; LC-MS/MS: liquid chromatography coupled to tandem mass spectrometry; LOD: limit of detection; LOQ: limit of quantitation; MeOH: methanol; NI: not identified; NFT: nitrofurantoin; NFZ: nitrofurazone; OCP: organochlorinated pesticides; PAH: polycyclic aromatic hydrocarbons; PBB: polybrominated biphenyls; PBDE: polybrominated diphenyls ethers; PCB: polychlorinated biphenyls; PCBD: polychlorinated dibenzofurans; PCDD: polychlorinated dibenzodioxins; PET: petroleum ether; RRLC-MS/MS: rapid resolution liquid chromatography-tandem mass spectrometry; S/N ratio: signal to noise ratio; SAX/PSA: strong anion exchange/primary-secondary amine cartridges; SEM: semicarbazide; SFE: supercritical fluid extraction; SPE: solid phase extraction; TFA: trifluoroacetic acid; Tol: toluene; UHPLC-MS/MS: ultra high performance liquid chromatography coupled to tandem mass spectrometry. 